Pacific Northwest

National Laboratory

Operated by Battelle for the

U.S. Department of Energy

\section{Influence of Nitrate on the Hanford 100D Area in Situ Redox Manipulation Barrier Longevity}

\author{
J. E. Szecsody \\ J. L. Phillips \\ V. R. Vermeul \\ J. S. Fruchter \\ M. D. Williams
}

June 2005

Prepared for the U.S. Department of Energy under Contract DE-AC05-76RL01830 


\title{
DISCLAIMER
}

This report was prepared as an account of work sponsored by an agency of the United States Government. Neither the United States Government nor any agency thereof, nor Battelle Memorial Institute, nor any of their employees, makes any warranty, express or implied, or assumes any legal liability or responsibility for the accuracy, completeness, or usefulness of any information, apparatus, product, or process disclosed, or represents that its use would not infringe privately owned rights. Reference herein to any specific commercial product, process, or service by trade name, trademark, manufacturer, or otherwise does not necessarily constitute or imply its endorsement, recommendation, or favoring by the United States Government or any agency thereof, or Battelle Memorial Institute. The views and opinions of authors expressed herein do not necessarily state or reflect those of the United States Government or any agency thereof.

\author{
PACIFIC NORTHWEST NATIONAL LABORATORY \\ operated by \\ BATTELLE \\ for the \\ UNITED STATES DEPARTMENT OF ENERGY \\ under Contract DE-AC05-76RL01830 \\ Printed in the United States of America \\ Available to DOE and DOE contractors from the \\ Office of Scientific and Technical Information, P.O. Box 62, Oak Ridge, TN 37831; \\ prices available from (615) 576-8401. \\ Available to the public from the National Technical Information Service, \\ U.S. Department of Commerce, 5285 Port Royal Rd., Springfield, VA 22161
}




\title{
Influence of Nitrate on the Hanford 100D Area In Situ Redox Manipulation Barrier Longevity
}

\author{
J. E. Szecsody \\ J. L. Phillips \\ V. R. Vermeul \\ J. S. Fruchter \\ M. D. Williams
}

June 2005

Prepared for

the U.S. Department of Energy

under Contract DE-AC05-76RL01830

Pacific Northwest National Laboratory

Richland, Washington 99352 


\begin{abstract}
The purpose of this laboratory study is to determine the influence of nitrate on the Hanford 100D Area in situ redox manipulation (ISRM) barrier longevity. There is a wide spread groundwater plume of $60 \mathrm{mg} / \mathrm{L}$ nitrate upgradient of the ISRM barrier with lower nitrate concentrations downgradient, suggestive of nitrate reduction occurring. Batch and 1-D column experiments showed that nitrate is being slowly reduced to nitrite and ammonia. These nitrate reduction reactions are predominantly abiotic, as experiments with and without bactericides present showed no difference in nitrate degradation rates. Nitrogen species transformation rates determined in experiments covered a range of ferrous iron/nitrate ratios such that the data can be used to predict rates in field scale conditions. Field scale reaction rate estimates for $100 \%$ reduced sediment $\left(16^{\circ} \mathrm{C}\right)$ are: a) nitrate degradation $=202 \pm 50 \mathrm{~h}$ (half-life), b) nitrite production $=850 \pm 300 \mathrm{~h}$, and c) ammonia production $=650 \pm 300 \mathrm{~h}$.

Calculation of the influence of nitrate reduction on the 100D Area reductive capacity requires consideration of mass balance and reaction rate effects. While dissolved oxygen and chromate reduction rates are rapid and essentially at equilibrium in the aquifer, nitrate transformation reactions are slow (100s of hours). In the limited (20-40 day) residence time in the ISRM barrier, only a portion of the nitrate will be reduced, whereas dissolved oxygen and chromate are reduced to completion. Assuming a groundwater flow rate of $1 \mathrm{ft} /$ day, it is estimated that the ISRM barrier reductive capacity is 160 pore volumes (with no nitrate), and 85 pore volumes if $60 \mathrm{mg} / \mathrm{L}$ nitrate is present (i.e., a $47 \%$ decrease in the ISRM barrier longevity). Zones with more rapid groundwater flow will be less influenced by nitrate reduction. For example, a zone with a groundwater flow rate of $3 \mathrm{ft} / \mathrm{day}$ and $60 \mathrm{mg} / \mathrm{L}$ nitrate will have a reductive capacity of 130 pore volumes. Finally, long-term column experiments demonstrated the longevity of the reduced sediment barrier to reduce/immobilize $2 \mathrm{mg} / \mathrm{L}$ chromate in the presence of $8.4 \mathrm{mg} / \mathrm{L}$ dissolved oxygen (saturation), and $60 \mathrm{mg} / \mathrm{L}$ nitrate (maximums observed in the field). Initially the chromate reduction half-life was $<0.1 \mathrm{~h}, 2.4 \mathrm{~h}$ by 120 pore volumes, and $17 \mathrm{~h}$ by 250 pore volumes. These chromate reduction rates are sufficiently fast relative to the 20 - 40 day residence time in the field for all chromate to be reduced/immobilized until the sediment is completely oxidized.
\end{abstract}




\section{Contents}

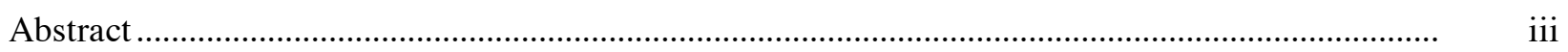

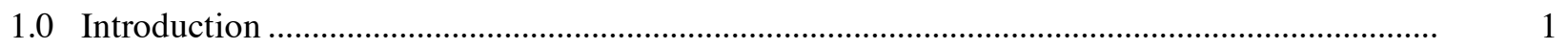

2.0 Background: Sediment Reduction and Oxidation Reactions ............................................... 1

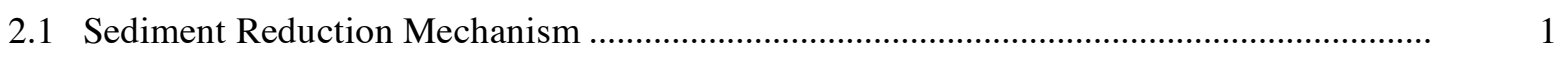

2.2 Sediment Oxidation and Chromate/Nitrate Reduction Mechanism .................................... 2

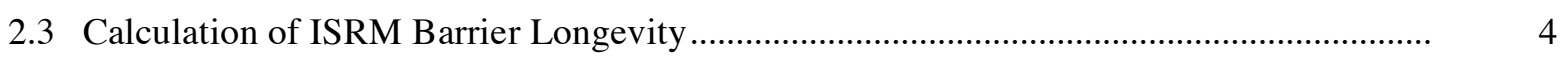

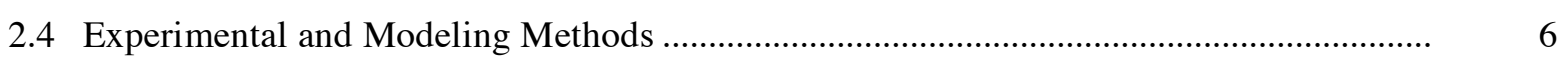

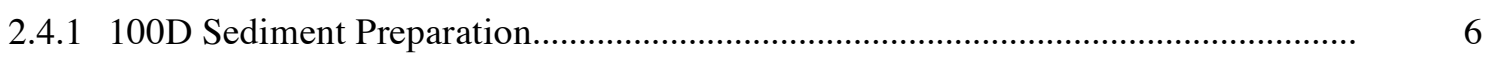

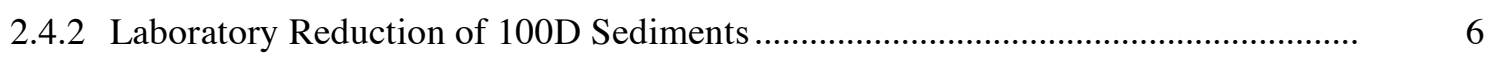

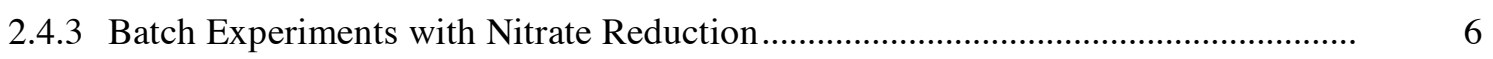

2.4.4 Batch Experiments with Nitrate, Chromate, and Oxygen Reduction ......................... 7

2.4.5 1-D Column Experiments and the Nitrate Reduction Rate ……................................. 7

2.4.6 1-D Column Experiments and Reduced Sediment Longevity ………....................... 8

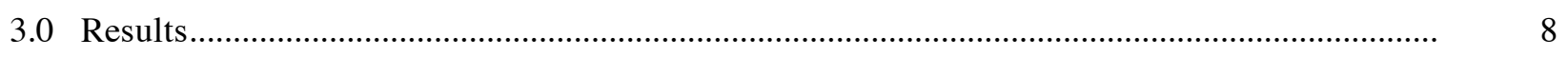

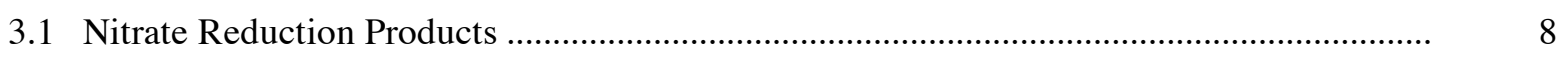

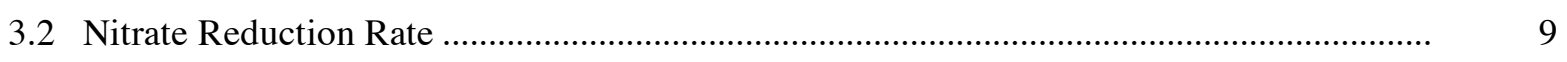

3.3 Abiotic and Biotic Control of Nitrate Reduction ................................................................... 13

3.4 Influence of Chromate and Oxygen on the Nitrate Reduction Rate ...................................... 14

3.5 Influence of Flow on the Nitrate Reduction Rate ................................................................. 15

3.6 Influence of Barrier Longevity on Nitrate and Chromate Reduction ................................. 16

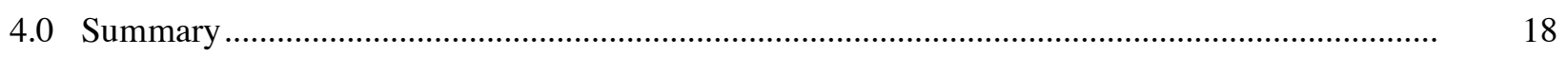

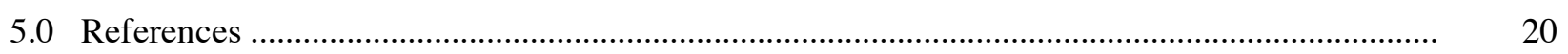

Appendix A - Batch Nitrate Reduction Experiments ...................................................................... A.1

Appendix B - 1-D Column Nitrate Reduction Experiments .......................................................... B.. B 


\section{Figures}

1 Nitrate reduction in a batch experiment with dithionite-reduced 100D composite sediment

2 Reaction rates in batch and column experiments as a function of the molar ratio of ferrous iron/nitrate.

3 Nitrate reduction in a batch experiment and reaction simulation fit to data

4 Nitrate reduction in a batch experiment with dithionite-reduced 100D composite sediment and bactericide

5 Calculated portioning of ammonia to the gas phase in $154 \mathrm{~mL}$ batch vials

6 Nitrate reduction in a batch experiment with dithionite-reduced 100D composite sediment in the presence of: a) chromate, and b) dissolved oxygen

7 Nitrate reduction in 1-D columns at different flow rates: a) $10 \mathrm{~h}$ residence time, b) $30 \mathrm{~h}$ residence time, c) $100 \mathrm{~h}$ residence time, and d) $100 \mathrm{~h}$ residence time.

8 Long term oxidation column experiment with a reduced sediment column in which

$2 \mathrm{mg} / \mathrm{L}$ chromate, $8.4 \mathrm{mg} / \mathrm{L} \mathrm{O}$, and $60 \mathrm{mg} / \mathrm{L}$ nitrate was injected

9 Long term oxidation column experiment with a reduced sediment column in which

$2 \mathrm{mg} / \mathrm{L}$ chromate, $8.4 \mathrm{mg} / \mathrm{L} \mathrm{O}$, and $60 \mathrm{mg} / \mathrm{L}$ nitrate was injected

10 Hanford 100D Area ground water nitrate concentrations in 2004.

11 Influence of nitrate reduction in the 100D Area ISRM barrier longevity

\section{Table}

1 Rates of nitrate and chromate reduction observed in batch and column experiments 


\subsection{Introduction}

The in situ redox manipulation (ISRM) groundwater barrier in the Hanford 100D Area was designed to prevent groundwater migration of a chromate plume into the Columbia River. This ISRM barrier consists of $\sim 70$ wells spaced across a 2300' section of the chromate plume. In the presence of $<2 \mathrm{mg} / \mathrm{L}$ chromate (maximum detected) and dissolved oxygen in water, the longevity of the barrier is approximately 180 pore volumes or 15 to 20 years, depending on the groundwater flow rate. The presence of a wide spread groundwater plume of $60 \mathrm{mg} / \mathrm{L}$ nitrate, if reduced in the ISRM barrier, could significantly reduce the barrier longevity. The purpose of this laboratory study is to determine the influence of nitrate on reduced sediment oxidation capacity. The specific research questions are:

- what reaction products are formed with nitrate reduction by dithionite-reduced 100D Area sediment (i.e., $\mathrm{NO}_{2}^{-}, \mathrm{NH}_{4}^{+}, \mathrm{N}_{2}$ )

- what are the nitrate reduction reaction rates

- what is the longevity of the reduced sediment (reductive capacity) in the presence of chromate, dissolved oxygen, and nitrate

- $\quad$ are microbes involved during nitrate reduction in these sediments

This laboratory investigation was initiated in the spring of 2005 using sediments from the Hanford $100 \mathrm{D}$ Area, boreholes D4-87, D4-88, and D4-89 (samples collected in 2002 and kept refrigerated). Research questions were investigated in small batch experiments and 1-D columns.

\subsection{Background: Sediment Reduction and Oxidation Reactions}

\subsection{Sediment Reduction Mechanism}

The In Situ Redox Manipulation (ISRM) approach involves the creation of a permeable treatment zone downstream of a contaminant plume or contaminant source through injection of a chemical reducing agent to alter the redox potential of aquifer fluids and sediments (Fruchter et al. 2000, 1994; Vermeul et al. 2002; Szecsody et al. 2004b, 2005). Redox-sensitive contaminants migrating through this treatment zone are immobilized (metals) or destroyed (organic solvents). Injected reagents create the zone through reactions that reduce iron naturally present in aquifer sediments from $\mathrm{Fe}$ (III) to $\mathrm{Fe}$ (II). The reducing agent used in these field and laboratory tests is sodium dithionite $\left(\mathrm{Na}_{2} \mathrm{~S}_{2} \mathrm{O}_{4}\right)$. Sodium dithionite is a strong reducing agent and it possesses a number of desirable characteristics for this type of application, including instability in the natural environment ( $\sim$ days) with reaction and degradation products, which ultimately oxidize to sulfate. A potassium carbonate/bicarbonate $\mathrm{pH}$ buffer is also added to the injection solution to enhance the stability of dithionite during the reduction of available iron.

The dithionite chemical treatment dissolves and reduces amorphous and some crystalline Fe(III) oxides (Szecsody et al. 2004b) and 2:1 smectite clays (Stucki et al. 1984). The reduced Fe(II) created by the dithionite chemical treatment appears to be present in several different $\mathrm{Fe}(\mathrm{II})$ phases: adsorbed $\mathrm{Fe}(\mathrm{II})$, $\mathrm{Fe}(\mathrm{II})$-carbonate (siderite), and FeS (iron sulfite), although adsorbed Fe(II) appears to be the dominant $\mathrm{Fe}(\mathrm{II})$ phase. There may be other, unidentified Fe(II) mineral phases produced. Although more than one 
iron (III) phase is likely reduced in a natural sediment, it can be useful to determine how simple a chemical model is needed to generally describe the observations. The reaction that describes a single phase of iron that is reduced by sodium dithionite:

$$
\mathrm{S}_{2} \mathrm{O}_{4}{ }^{-2}+2 \equiv \mathrm{Fe}^{3+}+2 \mathrm{H}_{2} \mathrm{O} \Leftrightarrow 2 \equiv \equiv \mathrm{Fe}^{2+}+2 \mathrm{SO}_{3}^{-2}+4 \mathrm{H}^{+}
$$

shows that the forward rate is a function of the dithionite concentration and the square of the reducible iron concentration (rate is overall a third-order function of concentration). The aqueous Fe(II) produced has a high affinity for surfaces, so is quickly adsorbed. Therefore, $\mathrm{Fe}(\mathrm{II})$ mobility in mid- to high $\mathrm{pH}$, low ionic strength groundwater is extremely limited, and iron is not expected to leach from sediments during the dithionite treatment. Aqueous iron measurements in previous studies have shown $<1 \%$ iron leaching even after 600 pore volumes of groundwater through a sediment column (Szecsody et al. 2004b). Corresponding solid iron measurements of sediments used in these columns showed 4-10\% loss of iron. Iron mobility is somewhat higher during the actual dithionite injection because, at high ionic strength $\left(\sim 0.3 \mathrm{~mol} / \mathrm{L}\right.$ in this case), other cations compete for the same adsorption sites as $\mathrm{Fe}^{2+}$, resulting in some $\mathrm{Fe}^{2+}$ desorption. If the number of slowly reducing sites is small and the mass of iron is far in excess of the dithionite, reaction 1 can be reduced to a first-order reaction in which $\mathrm{Fe}^{3+}$ remains constant. Another reaction occurs in the system, which describes the disproportionation of dithionite in contact with sediment:

$$
2 \mathrm{~S}_{2} \mathrm{O}_{4}^{-2}+\mathrm{H}_{2} \mathrm{O} \Leftrightarrow \mathrm{S}_{2} \mathrm{O}_{3}^{-2}+2 \mathrm{HSO}_{3}^{-}
$$

This reaction accounts for the mass loss of dithionite that cannot be used for iron reduction. Previous studies have shown that this reaction has a half-life of $\sim 27 \mathrm{~h}$ (basaltic sediments). The consequence of this reaction is to limit how slowly dithionite can be reacted with sediment in the field (i.e., minimum injection rate). If dithionite is injected too slowly, a significant amount of the mass is lost to disproportionation. Although iron(III) phases are the most significant phase that reacts with dithionite, other mineral phases present in natural sediments may also be reduced, and utilize some of the dithionite. Previous studies have shown that some Mn reduction occurs as a result of the dithionite treatment of Hanford sediment, although reduced $\mathrm{Mn}^{\text {II }}$ phases were only 3 to $4 \%$ relative to reduced iron phases. Ferrous iron associated with iron oxides also appear to act as a semiconducting surface that facilitates electron transfer, which is more effective than simple electron transfer from aqueous ferrous iron alone (Balko et al. 1998; Scherer et al. 1999; Wehrli 1992).

\subsection{Sediment Oxidation and Chromate/Nitrate Reduction Mechanism}

The oxidation of the adsorbed and structural Fe(II) in the sediments of the permeable redox barrier occurs naturally by the inflow of dissolved oxygen and other contaminants such as chromate, nitrate, uranium, technetium, trichloroethylene, carbon tetrachloride, and other electron acceptors. If redox equilibrium completely defined the mechanism (i.e., no effects from activation energies or surface catalysis) and the following contaminants were present in equal molar concentrations, they would be reduced in the following order:

$$
\text { chromate }>\text { dissolved oxygen }>\text { nitrate }>\text { uranium }>\text { pertechnetate }>\text { TCE }
$$

In most aquifers, dissolved oxygen in water is the dominant oxidant of reduced iron species, as contaminants are generally present in lower molar concentrations relative to dissolved oxygen. Note that chromate reduction should not be influenced by the presence of dissolved oxygen (assuming sufficient 
reductant is present), but nitrate reduction should occur more slowly in the presence of dissolved oxygen (i.e., dissolved oxygen will be reduced first, then the nitrate). The oxidation of reduced iron in pure mineral phases is described by the following reactions for dissolved oxygen and chromium. Fe(II) species that are known to exist in the dithionite-reduced sediments include adsorbed $\mathrm{Fe}(\mathrm{II})$ and siderite [Fe(II) $\mathrm{CO}_{3}$ ]. A single mole of electrons is consumed as a mole of these species are oxidized:

$$
\begin{gathered}
\mathrm{Fe}^{2+} \Leftrightarrow \mathrm{Fe}^{3+}+e^{-} \mathrm{Eh}=-0.771 \mathrm{v} \\
\mathrm{FeCO}_{3}(\mathrm{~s})+3 \mathrm{H}_{2} \mathrm{O} \Leftrightarrow \mathrm{Fe}(\mathrm{OH})_{3}(\mathrm{~s})+2 \mathrm{H}^{+}+\mathrm{HCO}_{3}^{-}+e^{-}
\end{gathered}
$$

The use of dissolved oxygen as an oxidant is generally divided into two electron sequences, which combined:

$$
\mathrm{O}_{2}+4 \mathrm{H}^{+}+4 e^{-} \Leftrightarrow \mathrm{H}_{2} \mathrm{O}, \quad \mathrm{Eh}=1.23 \mathrm{v}
$$

show that 4 moles of electrons are needed per mole of $\mathrm{O}_{2}$ consumed. The rate of this reaction (6) has generally been observed to be first-order at fixed $\mathrm{pH}$ and the rate increases 100 fold for a unit increase in pH (Pratt et al. 1997; Blowes et al. 1997). Experimental evidence during iron oxidation experiments indicates that two differing reduced iron species is present (adsorbed ferrous iron and siderite). Combining the two iron oxidation half reactions with oxygen reduction:

$$
\begin{aligned}
& 4 \equiv \mathrm{Fe}^{2+}+\mathrm{O}_{2}+4 \mathrm{H}^{+} \Leftrightarrow 4 \equiv \mathrm{Fe}^{3+}+\mathrm{H}_{2} \mathrm{O} \quad \mathrm{Eh}=-1.85 \mathrm{v} \\
& 4 \equiv \mathrm{FeCO}_{3}(\mathrm{~s})+\mathrm{O}_{2}+4 \mathrm{H}^{+} \Leftrightarrow 4 \equiv \mathrm{Fe}^{3+}+2 \mathrm{H}_{2} \mathrm{O}+4 \mathrm{CO}_{3}{ }^{2-}
\end{aligned}
$$

yield 4 moles of $\mathrm{Fe}(\mathrm{II})$ are oxidized and 4 moles of electrons transferred per mole of $\mathrm{O}_{2}$ consumed. At oxygen-saturated conditions $\left(8.4 \mathrm{mg} \mathrm{L}^{-1} \mathrm{O}_{2}, 1 \mathrm{~atm}, 25^{\circ} \mathrm{C}\right), 1.05 \mathrm{mmol} \mathrm{L}^{-1} \mathrm{Fe}(\mathrm{II})$ is consumed.

Experimental evidence indicates that the oxygenation of $\mathrm{Fe}(\mathrm{II})$ in solutions $(\mathrm{pH}>5)$ is generally found to be first order with respect to $\mathrm{Fe}(\mathrm{II})$ and $\mathrm{O}_{2}$ concentration and second-order with respect to $\mathrm{OH}-$. The rate of oxidation of aqueous $\mathrm{Fe}^{2+}$ by oxygen at $\mathrm{pH} 8$ is a few minutes (Eary and Rai 1988; Buerge and Hug 1997). In contrast, the oxidation rate (as a half-life) observed in natural sediments [surface $\mathrm{Fe}(\mathrm{II})$ phases mainly adsorbed $\mathrm{Fe}$ (II) and $\mathrm{Fe}(\mathrm{II}) \mathrm{CO}_{3}$ ] was found to be 0.3 to $1.1 \mathrm{~h}$ (Szecsody et al. 2000, 2004b). The Hanford $100 \mathrm{D}$ Area aquifer is generally about half-saturated with respect to oxygen (about $4-5 \mathrm{mg} \mathrm{L}^{-1}$ ).

The reduction rate of $\mathrm{Cr}(\mathrm{VI})$ species by ferrous iron has been extensively studied under various geochemical conditions. For chromate:

$$
\mathrm{CrO}_{4^{-}}+4 \mathrm{H}_{2} \mathrm{O}+3 e^{-} \Leftrightarrow \mathrm{Cr}(\mathrm{OH})_{3}+5 \mathrm{OH}-\quad \mathrm{Eh}=-0.13 \mathrm{v}
$$

3 mole of electrons are consumed per mole of chromate reduced. Since the reduction potential of this half reaction (9) per electron is greater than that for oxygen (7), chromate reduction would proceed before oxygen and more rapidly in the presence of ferrous iron, if present in equimolar concentrations with dissolved oxygen (and activation energy did not affect the reaction rate). The reduction of one mole of chromate oxidizes three mole of Fe(II), or $41 \mathrm{mg} \mathrm{L}^{-1}$ chromate is needed to oxidize the equivalent mass of $\mathrm{Fe}(\mathrm{II})$ as water saturated with dissolved oxygen $\left[1.05 \mathrm{mmol} \mathrm{L}^{-1} \mathrm{Fe}(\mathrm{II})\right]$.

Chromate at the Hanford aquifer pH of 7.7 to 8.3 exhibits essentially no adsorption (Zachara et al. 1987), whereas at low pH, considerable chromate adsorption has been observed (Jardine et al. 1999; Seaman et al. 1999). Although reaction (9) is written as a Cr(III) hydroxide, in actuality, mixed (Fe, $\mathrm{Cr}$ ) 
hydroxide phases precipitate. With excess iron to $\mathrm{Cr}$, the solubility of these mixed phase precipitates is orders of magnitude less than $\mathrm{Cr}(\mathrm{OH})_{3}$ (Sass and Rai 1986; Blowes et al. 1997; Boursiquot et al. 2002), which makes the reduced sediment concept for immobilization of chromate ideal under alkaline $\mathrm{pH}$ conditions. Interestingly, although chromate reduction does occur at low $\mathrm{pH}$, several $\mathrm{Cr}$ (III) species are formed and some are mobile (aqueous). In addition, ferrous iron that is adsorbed under alkaline conditions is mobile under acidic conditions. Reduced sediment barriers can still be effective even under highly acidic conditions (pH 4.3; Loyaux-Lawniczak et al. 2000, 2001; Jardine et al. 1999, Anderson et al. 1994) because immobile ferrous iron from 2:1 smectite clays or iron sulfides are the electron donors not adsorbed ferrous iron (Kim et al. 2001; Patterson and Fendorf 1997).

Nitrate reduction reactions of significance include:

$$
\begin{aligned}
& \mathrm{NO}_{3}^{-},+2 \mathrm{H}^{+}+2 \mathrm{e}-<->\mathrm{NO}_{2}^{-},+2 \mathrm{H}_{2} \mathrm{O} \\
& 2 \mathrm{NO}_{2}^{-},+4 \mathrm{H}^{+}+4 \mathrm{e}-<->\mathrm{N}_{2}^{2-},+2 \mathrm{H}_{2} \mathrm{O} \\
& \mathrm{NO}_{2}^{-},+8 \mathrm{H}^{+}+6 \mathrm{e}^{-}<->\mathrm{NH}_{4}^{+},+2 \mathrm{H}_{2} \mathrm{O}
\end{aligned}
$$

which indicate that the conversion of one mole of nitrate to nitrate consumes two moles of electrons; one mole of nitrate to $\mathrm{N}_{2}$ consumes four moles of electrons, and one mole of nitrate to ammonia consumes eight moles of electrons. So the reduced sediment barrier longevity will be significantly less with greater reduction of the nitrate. The influence of nitrate can be easily shown by general cases in the 100D Area:

1) $4.2 \mathrm{mg} / \mathrm{L}$ oxygen, $1.0 \mathrm{ppm}$ chromate

2) $4.2 \mathrm{mg} / \mathrm{L}$ oxygen, $1.0 \mathrm{ppm}$ chromate, $60 \mathrm{ppm}$ nitrate to nitrite

3) $4.2 \mathrm{mg} / \mathrm{L}$ oxygen, $1.0 \mathrm{ppm}$ chromate, $60 \mathrm{ppm}$ nitrate to ammonia.

In the first case, the barrier should last about 122 pore volumes (i.e., 122x more ferrous iron than the two electron acceptors), but in the second case, the barrier capacity is reduced to $49 \mathrm{pv}$ (capacity reduced $60 \%$ ). In the third case, the barrier capacity is reduced to $20 \mathrm{pv}$ (capacity reduced $84 \%$ ). The reaction rates also highly influence the barrier capacity. As described earlier, oxidation of adsorbed ferrous iron in natural sediments has measured half-lives of $0.3 \mathrm{~h}$ to $1.1 \mathrm{~h}$. Chromate reduction (as described later in this report) is also rapid, with a measured half-life of minutes to hours. These reactions are rapid or nearly at equilibrium compared with the residence time at the field scale. An ISRM field scale barrier (30-50 ft wide barrier with a flow rate of $1 \mathrm{ft} /$ day) has a 30 to 50 day residence time of nonsorbing solutes in the barrier.

Alternatively, nitrate reduction reactions are slow, taking 100s of hours, so electron transfer reactions within the ISRM barrier will be dependent on the flow rate. Faster flow rate will consume less of the barrier (i.e., not enough time for conversion to ammonia). With the nitrate-to-nitrate reaction half-life of $200 \mathrm{~h}$, and a nitrite to ammonia reaction half life of another $650 \mathrm{~h}$, only a portion of these reactants will be converted to products within the barrier (average residence time 30 days or $720 \mathrm{~h}$ ). Fast flow regions with reported velocities of $3 \mathrm{ft} / \mathrm{day}$ will have greater capacity since less nitrate will be reduced.

\subsection{Calculation of ISRM Barrier Longevity}

The longevity of a dithionite-reduced zone can be determined from the ratio of ferrous iron phases (electron donor) in the sediments to the electron acceptors in the aquifer (dissolved oxygen, chromate, nitrate) that flow through the reduced zone. Several studies were done in the Hanford 100D Area to determine the mass of ferrous iron in the ISRM barrier. The "laboratory reductive capacity" refers to $120 \mathrm{~h}$ of $0.09 \mathrm{~mol} / \mathrm{L}$ dithionite treatment on a small laboratory column (i.e., excess dithionite/reducible iron for 5 days), so represents a maximum amount. The "field reductive capacity" refers to sediment 
cores taken after field dithionite treatment, so can be equal to the laboratory reductive capacity (if the core location was near an injection well) or significantly less than the laboratory reductive capacity (if the core location was far from an injection well).

In the 1997 study, the laboratory reductive capacity averaged $11.0 \pm 3.0 \mu \mathrm{mol} \mathrm{Fe} / \mathrm{II}$ for 18 samples. In the 1999 study, the field reductive capacity averaged $11.2 \pm 7.4 \mu \mathrm{mol} \mathrm{Fe} / \mathrm{II}$ for 8 field-reduced samples. Note that the mean capacity was the same but the standard deviation was greater for the fieldreduced samples. This is caused by field scale injections not uniformly treating the sediment (likely due to flow heterogeneities). In the 2002 study, the field reductive capacity averaged $10.6 \pm 7.5 \mu \mathrm{mol} \mathrm{Fe} / \mathrm{g}$ for 16 field-reduced samples and the laboratory (maximum) reductive capacity averaged $40.0 \pm 15.0$ $\mu \mathrm{mol} \mathrm{Fe} / \mathrm{II}$ for 7 samples. The 2002 study used cores from three boreholes (D4-87, D4-88, D4-89). There is a current study in progress in which the field reductive capacity is being quantified in 60 fieldreduced samples from 4 boreholes (D4-90, D4-91, D4-92, D4-93). Preliminary data from one borehole (D4-91) shows an averaged field reductive capacity of $9.55 \pm 3.6 \mu \mathrm{mol} \mathrm{Fe} / \mathrm{I}$ for 8 samples (by the same 1 -D column method) and a laboratory (maximum) reductive capacity of $36.9 \pm 5.5 \mu \mathrm{mol} \mathrm{Fe}{ }^{\mathrm{II}} / \mathrm{g}$ for 14 samples.

Calculation of the ISRM barrier longevity in pore volumes (nondimensional) or in years is the ratio of the electron donor to acceptors, but using field scale sediment physical parameters. The mass of electron donor (i.e., Fe(II) and other reduced transition metals) can be calculated per unit volume of water (i.e., pore space) in packed porous media as follows.

electron donor: moles of electrons per $\mathrm{cm}^{3}$ liquid from the $\mathrm{Fe}(\mathrm{II})$ :

$(11.2 \mu \mathrm{mol} \mathrm{Fe} / \mathrm{g})\left(1 \mathrm{e}^{-} / \mathrm{Fe}^{2+}\right)\left(2.3 \mathrm{~g}\right.$ sed. $\left./ \mathrm{cm}^{3}\right)\left(\mathrm{cm}^{3} / 0.14 \mathrm{~cm}^{3}\right.$ liquid $)\left(\mathrm{mol} / 10^{6} \mu \mathrm{mol}\right)\left(10^{3} \mathrm{~cm}^{3} / \mathrm{L}\right)$

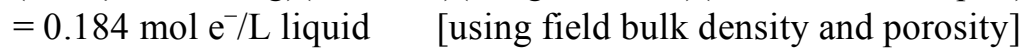

electron acceptors: moles of electrons per $\mathrm{cm}^{3}$ liquid from dissolved oxygen and other redox-reactive species $\left(\mathrm{CrO}_{4}^{2-}\right.$, TCE, $\left.\mathrm{RDX}, \mathrm{NO}_{3}^{-} \ldots\right)$ :

$\left(5.1 \mathrm{mg} / \mathrm{L} \mathrm{O}_{2}\right)(\mathrm{g} / 1,000 \mathrm{mg})(\mathrm{mol} \mathrm{O} / 2 / 32 \mathrm{~g})\left(4 \mathrm{~mol} \mathrm{e}^{-} / \mathrm{mol} \mathrm{O}_{2}\right)$ $=6.38 \times 10^{-4} \mathrm{~mol} \mathrm{e}^{-} / \mathrm{L}$

$\left(1.0 \mathrm{mg} / \mathrm{L} \mathrm{CrO}_{4}{ }^{-}\right)(\mathrm{g} / 1,000 \mathrm{mg})\left(\mathrm{mol} \mathrm{CrO}_{4}{ }^{2-} / 117 \mathrm{~g}\right)\left(3 \mathrm{~mol} \mathrm{e}-/ \mathrm{mol} \mathrm{CrO}_{4}{ }^{2-}\right)$ $=2.6 \times 10^{-5} \mathrm{~mol} \mathrm{e}^{-/} / \mathrm{L}$

$\left(45.0 \mathrm{mg} / \mathrm{L} \mathrm{CrO}_{4}{ }^{-}\right)(\mathrm{g} / 1,000 \mathrm{mg})\left(\mathrm{mol} \mathrm{NO}{ }_{3}{ }^{2-} / 62 \mathrm{~g}\right)\left(2 \mathrm{~mol} \mathrm{e}-/ \mathrm{mol} \mathrm{NO}_{3}{ }^{2-}\right)$

$=1.45 \times 10^{-3} \mathrm{~mol} \mathrm{e} / \mathrm{L}$

total electron acceptors $=6.38 \times 10^{-4}+2.6 \times 10^{-5}+1.45 \times 10^{-3}=2.1 \times 10^{-3} \mathrm{~mol} \mathrm{e}^{-} / \mathrm{L}$

barrier longevity: electron donors/electron acceptors (number of pore volumes barrier will last)

for $5.1 \mathrm{mg} / \mathrm{L} \mathrm{O}_{2}, 1.0 \mathrm{mg} / \mathrm{L} \mathrm{CrO}_{4}^{-}$, and $45.0 \mathrm{mg} / \mathrm{L} \mathrm{NO}_{3}{ }^{-2}$

$0.184 \mathrm{~mol} \mathrm{e} / \mathrm{L} / 2.1 \times 10^{-3} \mathrm{~mol} \mathrm{e} / \mathrm{L}$

$=88$ pore volumes

To determine the actual longevity in years, the average groundwater flow rate through that aquifer zone is needed. An estimated longevity in years, based on a groundwater flow rate of $1.0 \mathrm{ft} /$ day and an average reduced sediment barrier diameter of $30 \mathrm{ft}$ is calculated as follows. 


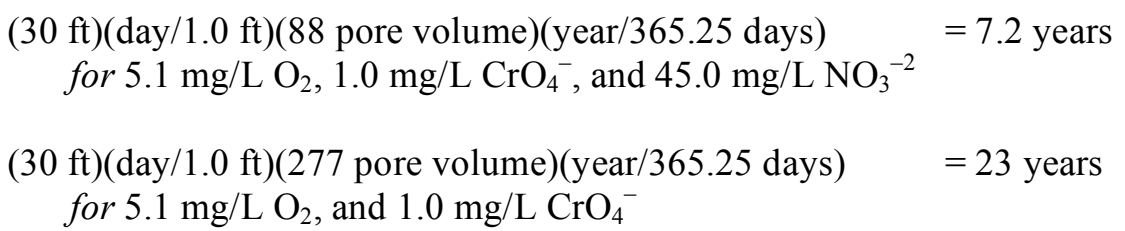

The above calculations assume a single, homogeneously reduced aquifer unit. At the 100D Area, there are aquifer zones present with differing flow rates (measured), possibly variation in iron content (hypothesized, current study ongoing), and reductive capacity (measured). Similar calculations can be made to approximate these differing characteristics to determine if premature breakthrough is predicted to occur in high flow zones.

\subsection{Experimental and Modeling Methods}

\subsubsection{D Sediment Preparation}

A composite of 100D sediments was used in this study from boreholes D4-87, 88, 89, and 90, from depths 80 ' to 100'. These sediments were collected in 2002 and have been stored anaerobically in a refrigerator since collection (used in a previous study). The $<4 \mathrm{~mm}$ size fraction of the composite was used, which represents $41 \%$ of the total grain size distribution by weight. Chemical extractions were conducted on the reduced sediments from 1-D columns in an anaerobic chamber to quantify the reductive capacity. The extractions consisted of a $0.5 \mathrm{M} \mathrm{HCl}$ for 1 hour (Heron et al. 1994a, b), with measurement of the ferrous iron by a colormetric ferrozine method (Gibbs 1976; Chao and Zhou 1983). This sediment extraction has been shown to produce similar reductive capacity measurements as the oxidation of the sediment in a 1-D column with oxygen-saturated water.

\subsubsection{Laboratory Reduction of 100D Sediments}

The dithionite chemical treatment dissolves and reduces amorphous and some crystalline Fe(III) oxides () and clays (Stucki et al. 1984). The reduced Fe(II) created by the dithionite chemical treatment appears to be present in several different Fe(II) phases: adsorbed Fe(II), Fe(II)-carbonate (siderite), and FeS (iron sulfite), although adsorbed Fe(II) appears to be the dominant Fe(II) phase. These reduction experiments consisted of injecting $0.09 \mathrm{~mol} / \mathrm{L}$ dithionite and $0.36 \mathrm{~mol} / \mathrm{L} \mathrm{K}_{2} \mathrm{CO}_{3}$ for $120 \mathrm{~h}$ at a constant flow rate with a $5.0 \mathrm{~h}$ residence time to fully reduce the sediment $\mathrm{Fe}(\mathrm{III})$-oxide and clay minerals (Szecsody et al. 2004b). The dry bulk density and porosity of the column will be calculated from the dry and saturated column weight and column volume. The volumetric flow rate was calculated from the effluent volume and elapsed time. After dithionite reduction, sediment is stored in glass vials under water with helium sparging and no headspace with $1-\mathrm{cm}$ thick septa. These glass septa top vials are stored then stored in a refrigerator. This "laboratory-reduced" 100D sediment represents a maximum amount of reduction that can be achieved. Field scale reduction is typically equal to this or less, depending on the dithionite contact time at the specific location.

\subsubsection{Batch Experiments with Nitrate Reduction}

Batch nitrate reduction experiments consist of mixing 2 to $8 \mathrm{~g}$ of dithionite-reduced sediment in a glass septa-top vial with 10 to $40 \mathrm{~mL}$ of $100 \mathrm{D}$ groundwater containing 10 to $60 \mathrm{mg} / \mathrm{L}$ nitrate. Preparation of the experiment consists of placing the wet, dithionite-reduced 100D composite sediment in the glass vial in an anaerobic chamber, immediately placing the specified amount of water with the sediment and sparging for $1 \mathrm{~h}$ with helium. While the anaerobic chamber has nearly no oxygen in it, the helium sparging actively scrubs out any trace amounts of oxygen from the experimental system. When sparging 
is completed, a small quantity of a nitrate stock solution is added, the vial is sealed with a 1-cm-thick septa, and the experiment is initiated. Typically multiple experiments are conducted simultaneously. Experiment vials are then placed on a slow rotary mixer. At specified time periods, 0.2 to $3 \mathrm{~mL}$ of water is removed from the vial with a needle and syringe, filtered, and analyzed for specific nitrogen-containing compounds. Hach colormetric kits were used for nitrate, nitrite, and ammonia analysis. Results were compared against standard solutions of these compounds.

The initial series of batch experiments (V3 to V6) were soil/water ranging experiments in which the nitrate to ferrous iron ratio varied between experiments. These consisted of $60 \mathrm{mg} / \mathrm{L}$ with $0.2 \mathrm{~g} / \mathrm{mL}$ $\left(\mathrm{Fe}^{\mathrm{II}} / \mathrm{NO} 3=4.1, \mathrm{~V} 3\right), 10 \mathrm{mg} / \mathrm{L}$ at $0.2 \mathrm{~g} / \mathrm{mL}\left(\mathrm{Fe}^{\mathrm{II}} / \mathrm{NO} 3=25, \mathrm{~V} 4\right), 10 \mathrm{mg} / \mathrm{L}$ with $0.5 \mathrm{~g} / \mathrm{mL}\left(\mathrm{Fe}^{\mathrm{II}} / \mathrm{NO} 3=64\right.$, $\mathrm{V} 5)$, and $5 \mathrm{mg} / \mathrm{L}$ with $0.5 \mathrm{~g} / \mathrm{mL}\left(\mathrm{Fe}^{\mathrm{II}} / \mathrm{NO} 3=127, \mathrm{~V} 6\right)$. These experiments were sampled for nitrate and nitrite. The field system has $60 \mathrm{mg} / \mathrm{L}$, but at $5 \mathrm{~g} / \mathrm{mL}\left(\left(\mathrm{Fe}^{\mathrm{II}} / \mathrm{NO} 3=103\right)\right.$. These experiments were sampled at time intervals until $250 \mathrm{~h}$. The second series of batch experiments consisted of fixing the soil/water ratio at $0.2 \mathrm{~g} / \mathrm{mL}$ and nitrate initial concentration at $10 \mathrm{mg} / \mathrm{L}$. One experiment was conducted with no additional modification and was sampled at periodic intervals to $1200 \mathrm{~h}$ (V7). Five additional experiments were conducted in parallel, but with the addition of differing bactericides to the sediment/water system. These included $1 \% 0.6$ gluteraldehyde (V8a), $2 \mathrm{mM}$ ammonium molybdate tetrahydrate (V8b), and $6 \mathrm{mM}$ sodium 2-bromoethanesulfonate (V8c). One additional experiment used a Co-60 source to gamma irridiate the reduced sediment to kill microbes (without $\mathrm{N}$ analysis interference). The presence of a bactericide is for the purpose of killing microbes, but without influencing the contaminant (i.e., nitrate in this case) abiotic reactions. In a separate project, we successfully used these bactericides with RDX (an explosive), but in contrast $\mathrm{HgCl}_{2}$ (another bactericide) oxidized the reduced sediment (so is not a useful bactericide for this purpose, Szecsody et al. 2004a).

\subsubsection{Batch Experiments with Nitrate, Chromate, and Oxygen Reduction}

Batch experiments were conducted to determine the influence of other reductants present in the field on the rate of nitrate reduction. Because chromate and oxygen are both reduced before nitrate, both should slow the rate of nitrate reduction (in a system with limited ferrous iron). One batch experiment was conducted in which both nitrate and chromate were present as electron acceptors. In this experiment, $8 \mathrm{~g}$ of reduced sediment were mixed with $40 \mathrm{~mL}$ of water containing $10 \mathrm{mg} / \mathrm{L}$ nitrate (total $0.013 \mathrm{meq}$ e-acceptor) and $2 \mathrm{mg} / \mathrm{L} \mathrm{Cr}$ as chromate (0.0046 meq e-acceptor). The sediment had an estimated 160 meq ferrous iron as e-donor. While the hypothesis is correct from a thermodynamic basis, because the electron acceptor quantities were small relative to the donor capacity of the sediment. A batch experiment was also conducted in parallel with experiment V7 (Figure 1) in which both nitrate and dissolved oxygen were present as electron acceptors. Oxygen should be thermodynamically reduced before nitrate. In this experiment, $8 \mathrm{~g}$ of reduced sediment were mixed with $40 \mathrm{~mL}$ of water containing $10 \mathrm{mg} / \mathrm{L}$ nitrate (total $0.013 \mathrm{meq}$ e-acceptor) and $2 \mathrm{mg} / \mathrm{L}$ dissolved oxygen ( $0.525 \mathrm{meq}$ e-acceptor).

\subsubsection{1-D Column Experiments and the Nitrate Reduction Rate}

A series of 1-D column experiments were conducted to quantify the nitrate reduction rate under fieldscale soil/water ratios. In these experiments $60 \mathrm{mg} / \mathrm{L}$ nitrate (anaerobic, no oxygen) was injected into a reduced 100D Area $<4 \mathrm{~mm}$ composite sediment column at a constant flow rate and effluent samples were collected over several pore volumes. Three column experiments were conducted in this series with a $10 \mathrm{~h}$ (V13), $30 \mathrm{~h}$ (V14), and $100 \mathrm{~h}$ (V15) residence time. Measurement of the nitrate and reaction products at the different flow rates provides a robust measurement of the reaction rates. An additional column 


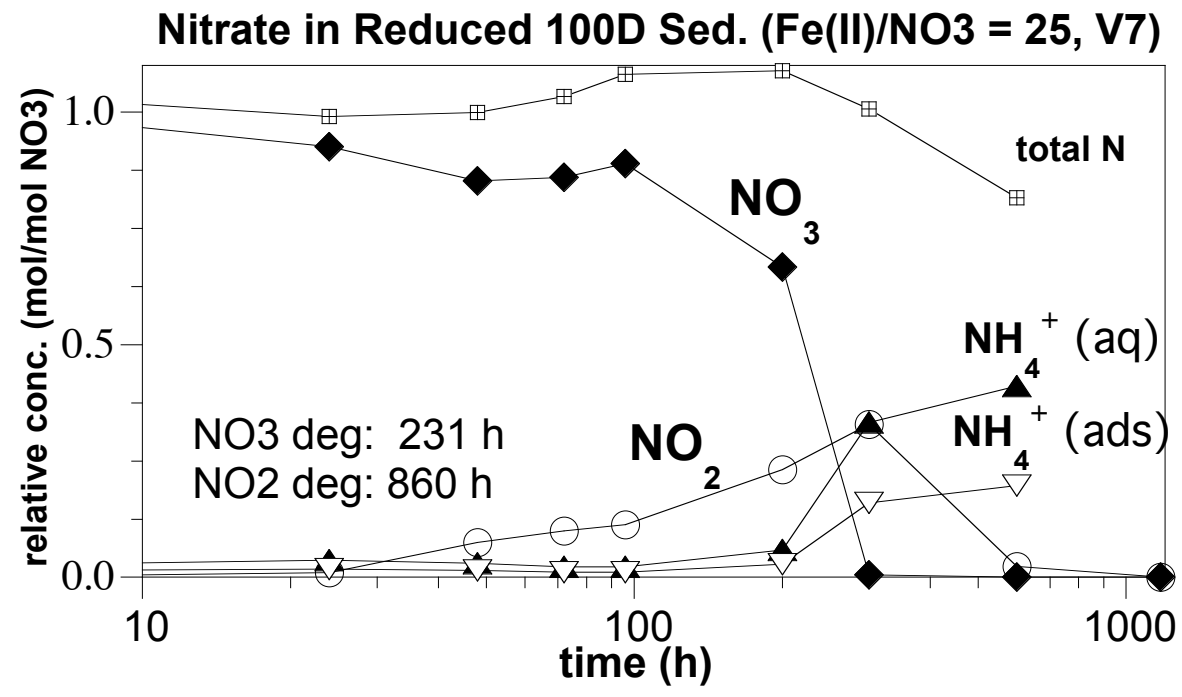

Figure 1. Nitrate reduction in a batch experiment with dithionite-reduced 100D composite sediment $(<4 \mathrm{~mm})$.

experiment was then conducted in which $60 \mathrm{mg} / \mathrm{L}$ nitrate and $8.4 \mathrm{mg} / \mathrm{L}$ dissolved oxygen (saturated) was injected into the sediment column at a constant flow rate to achieve a $100 \mathrm{~h}$ residence time (V16) in order to compare the influence of the presence of dissolved oxygen on the nitrate reduction rate.

\subsubsection{1-D Column Experiments and Reduced Sediment Longevity}

A series of column experiments were then initiated to test the nitrate, oxygen, and chromate reduction rates at different points along the barrier life cycle. This reduced sediment column should last $\sim 250$ pore volumes, being mainly oxidized by dissolved oxygen. The experimental setup is injection of $60 \mathrm{ppm}$ nitrate, $8.4 \mathrm{ppm}$ dissolved oxygen, and $2.0 \mathrm{ppm}$ chromate at a $10 \mathrm{~h}$ residence time for 4 pore volumes with measurement of nitrate, oxygen, and chromate. With a $10 \mathrm{~h}$ residence time, nearly all of the dissolved oxygen and chromate is reduced, but only about $5 \%$ of the nitrate is reduced. After data is collected for 4 pore volumes ( $10 \mathrm{~h}$ residence time), the flow rate is increased to achieve a $1.0 \mathrm{~h}$ residence time for 50 pore volumes, during which time only dissolved oxygen in the effluent is measured. With a $1.0 \mathrm{~h}$ residence time, most of the dissolved oxygen and chromate is reduced, but very little nitrate $(<0.5 \%)$ is reduced. The is cycle of 4 pore volumes at slow flow rate $(10 \mathrm{~h}$ residence time) followed by 50 pore volumes at a rapid flow rate ( $1 \mathrm{~h}$ residence time) is repeated for 250 pore volumes to collect oxygen, nitrate, and chromate reduction rate data as the reduced sediment is being oxidized.

\subsection{Results}

\subsection{Nitrate Reduction Products}

Batch experiments clearly show that nitrate is being reduced to nitrate and ammonia (Figure 1, additional experiments in Appendix A). For the conditions of this experiment, nitrate degraded with a $230 \mathrm{~h}$ half-life, nitrite production half-life was $525 \mathrm{~h}$, and ammonia (both aqueous and sorbed) production half-life was $302 \mathrm{~h}$. Other experiments showed the same general results, with rates of nitrate degradation and product formation increased with a higher ferrous iron/nitrate ratio (described in the next section). 
The total nitrogen balance (molar sum of all measured $\mathrm{N}$ species) was good until $250 \mathrm{~h}$, after which time there was a loss, which increased to $15 \%$ by $600 \mathrm{~h}$. Adsorbed ammonia accounted for part of the mass loss. At pH 8 in Hanford 100D sediments, there was no adsorption of nitrate and nitrite, but there was adsorption of ammonia $(\mathrm{Kd}$ $=2.5 \mathrm{~cm}^{3} / \mathrm{g}$ ). Ammonia adsorption was measured in a separate experiment and the mass of adsorbed ammonia was calculated in Figure 1 (i.e., only aqueous ammonia was measured). The total nitrogen loss may be indicative of some production of $\mathrm{N}_{2}$ gas (which was not measured), or some other error in compounds measured (nitrate, nitrite, ammonia). The possibility of ammonia loss to the gas phase was also investigated as there is headspace in batch experiments. Henry's Law calculations showed that due to the low vapor pressure of ammonia, loss to the gas phase is insignificant $(<0.02 \%$, described in a later section).

\subsection{Nitrate Reduction Rate}

A total of eight batch and nine column experiments were conducted with a range of differing ratios of the two reactants; ferrous iron (electron donor) and nitrate (electron acceptor). At a higher molar ratio of ferrous iron to nitrate (Figure 2a), nitrate reduction occurred more quickly. This is indicative (but does not prove) that the reaction is abiotic (i.e., dependent on the ferrous iron concentration). The possibility that one or more of the $\mathrm{N}$-compound reduction reactions are biotic (microbial) or coupled abiotic/biotic was investigated, and is described in a later section.

Theoretically, two moles of electrons from ferrous iron (reaction 4) are needed to reduce one mole of nitrate (reaction 10), so the reaction is second order with respect to ferrous iron. The experimental data shows that the change in the nitrate degradation rate is less than first order (exponent 0.67 , Figure 2a), so the observed reaction rate is not entirely controlled by the chemical reduction of nitrate by surface ferrous iron. It is likely that there is some surface diffusion control for the different ferrous iron species donating electrons (adsorbed ferrous iron,
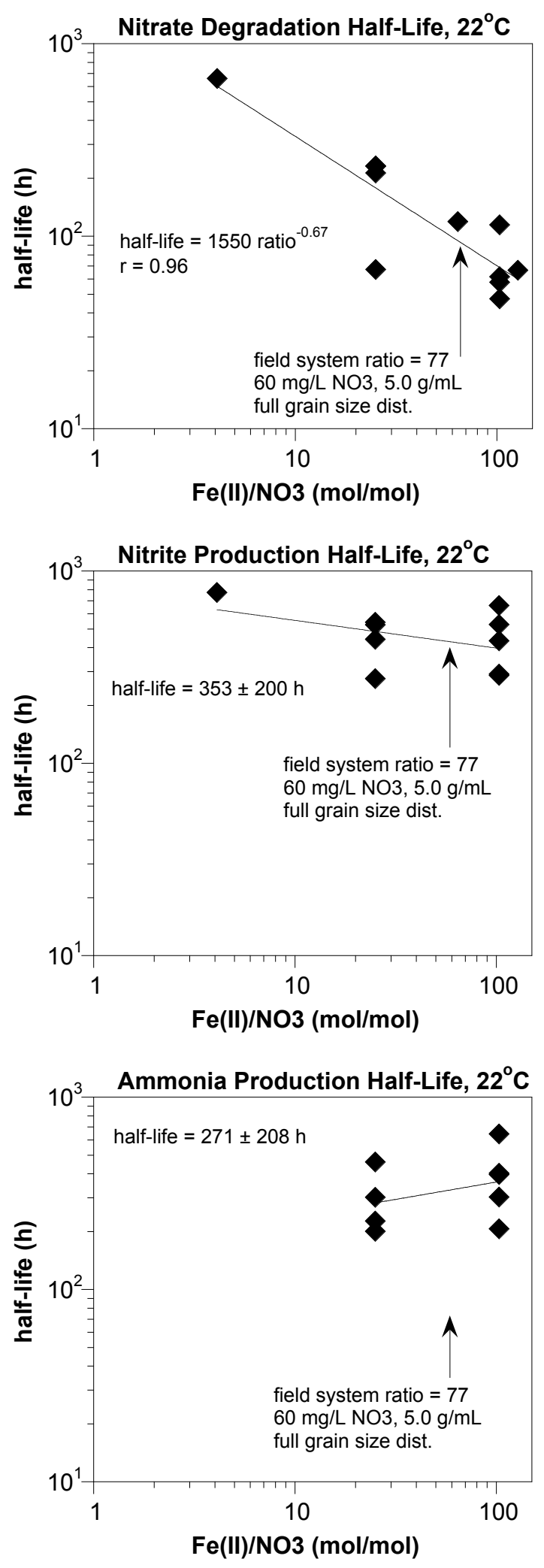

Figure 2. Reaction rates in batch and column experiments as a function of the molar ratio of ferrous iron/nitrate. 
ferrous iron in iron oxides and 2:1 smectite clays). The observed data shows that increasing the ferrous iron concentration by $6 x$ (ratio of 4.1 to 25 ), the nitrate reduction rate increased $3.3 x$. In addition, increasing the ferrous iron concentration by $25 \mathrm{x}$ (ratio of 4.1 to 103), the nitrate reduction rate increased $9.4 \mathrm{x}$.

The rate of production of nitrite was nearly independent of changes in the ferrous iron concentration (Figure 2b), as was the rate of production of ammonia (Figure 2c). This may be indicative of these slower reactions being predominantly controlled by something other than the actual chemical redox reaction, such as surface diffusion.

Use of the laboratory batch and 1-D column experimental data presented here to predict nitrate reaction rates in the Hanford 100D Area aquifer require accounting for the following differences: a) actual ferrous iron/nitrate molar ratio at the field scale, b) full grain size distribution (rather than the $<4 \mathrm{~mm}$ size used in laboratory experiments, c) $15^{\circ} \mathrm{C}$ to $17^{\circ} \mathrm{C}$ aquifer temperature. The first two factors can be accounted for given the ferrous iron concentration in the $<4 \mathrm{~mm}$ size fraction, the $41 \%$ of the size fraction is $<4 \mathrm{~mm}$, the assumed $60 \mathrm{mg} / \mathrm{L}$ nitrate upgradient of the 100D Area ISRM barrier, and the laboratory and field-scale bulk densities and porosities:

laboratory 1-D column system with ratio of $103 \mathrm{~mol} \mathrm{Fe} / \mathrm{mol} \mathrm{NO}_{3}$ :

$103 \mathrm{~mol} / \mathrm{mol} \times 1 /\left[1.85 \mathrm{~g} / \mathrm{cm}^{3} \times 1 / 0.33 \times 0.41<4 \mathrm{~mm} / \mathrm{all}\right] \times\left[2.05 \mathrm{~g} / \mathrm{cm}^{3} \times 1 / 0.20\right]=77 \mathrm{~mol} / \mathrm{mol}$ [laboratory bulk density, porosity] [field bulk density, porosity]

These factors produce a final ferrous iron/nitrate ratio of 77 . At this field iron/nitrate ratio, laboratory the $22^{\circ}$ C laboratory data $(100 \%$ reduced sediment $)$ indicates:

nitrate degradation $\left(22^{\circ} \mathrm{C}, \mathrm{Fe} / \mathrm{NO}_{3}=77\right) \quad=84 \pm 35 \mathrm{~h}$ (half-life)

nitrite production $\left(22^{\circ} \mathrm{C}, \mathrm{Fe} / \mathrm{NO}_{3}=77\right) \quad=353 \pm 200 \mathrm{~h}$ (half-life)

ammonia production $\left(22^{\circ} \mathrm{C}, \mathrm{Fe} / \mathrm{NO}_{3}=77\right)=271 \pm 208 \mathrm{~h}$ (half-life)

which can be altered to the $15^{\circ} \mathrm{C}$ to $17^{\circ} \mathrm{C}$ aquifer temperature $\left(2^{\circ} \mathrm{C}\right.$ seasonal variation $)$ if the change in the reaction rate with temperature is known. The change in nitrate reduction rate with temperature was not determined in this study. However, other studies have shown reaction rate changes with temperature for related redox reactions including: a) dithionite reduction of sediment $\left.\left(0.44 \mathrm{x} /{ }^{\circ} \mathrm{C}\right), \mathrm{b}\right)$ dithionite disproportionation $\left(0.30 \mathrm{x} /{ }^{\circ} \mathrm{C}\right)$, c) TCE degradation by reduced sediment $\left(0.40 \mathrm{x} /{ }^{\circ} \mathrm{C}\right)$, and d) RDX degradation by reduced sediment $0.72 \mathrm{x} /{ }^{\circ} \mathrm{C}$ ). Using an estimate of $0.40 \mathrm{x}$ decrease in the nitrate reduction reactions for each $1^{\circ} \mathrm{C}$ decrease, best estimate of field scale rates are:

nitrate degradation $\left(16^{\circ} \mathrm{C}, \mathrm{Fe} / \mathrm{NO}_{3}=77\right)=202 \pm 50 \mathrm{~h}$ (half-life)

nitrite production $\left(16^{\circ} \mathrm{C}, \mathrm{Fe} / \mathrm{NO}_{3}=77\right) \quad=850 \pm 300 \mathrm{~h}$ (half-life)

ammonia production $\left(16^{\circ} \mathrm{C}, \mathrm{Fe} / \mathrm{NO}_{3}=77\right)=650 \pm 300 \mathrm{~h}$ (half-life)

Degradation rates are slower in sediments that are less reduced than the high reduction achieved in laboratory experiments here. These rates are used in the summary section to estimate the barrier longevity as a function of the nitrate residence time in the barrier (Table 1). 
Table 1. Rates of nitrate and chromate reduction observed in batch and column experiments.

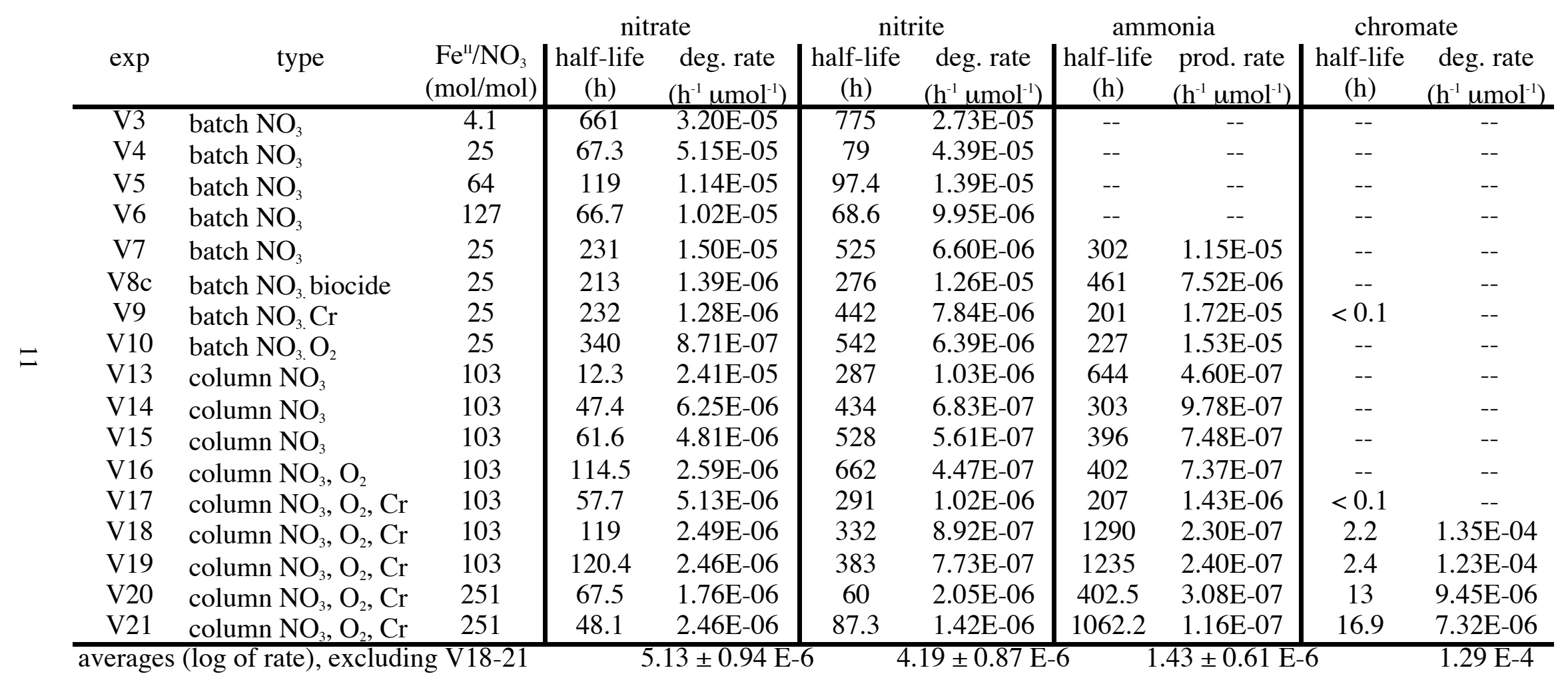


Given the reaction rates established in the batch and column experiments in this study, a reaction simulator was used to approximate data (Figure 3). In this simulation, the theoretical two-electron transfer for the nitrate to nitrite reaction was used (reaction 10). The fit to the data was only approximate, as the slope indicated a different reaction order (lower order for $\mathrm{Fe}^{\mathrm{II}}$ ) than the second-order reaction fit (as previously described). However, mass transfer from nitrate to nitrite to ammonia was generally fit by the simulation. This type of simulation can then be used to estimate the reaction product distributions in the field over time, as the ferrous iron/nitrate ratio decreases (i.e., the reaction will slow).
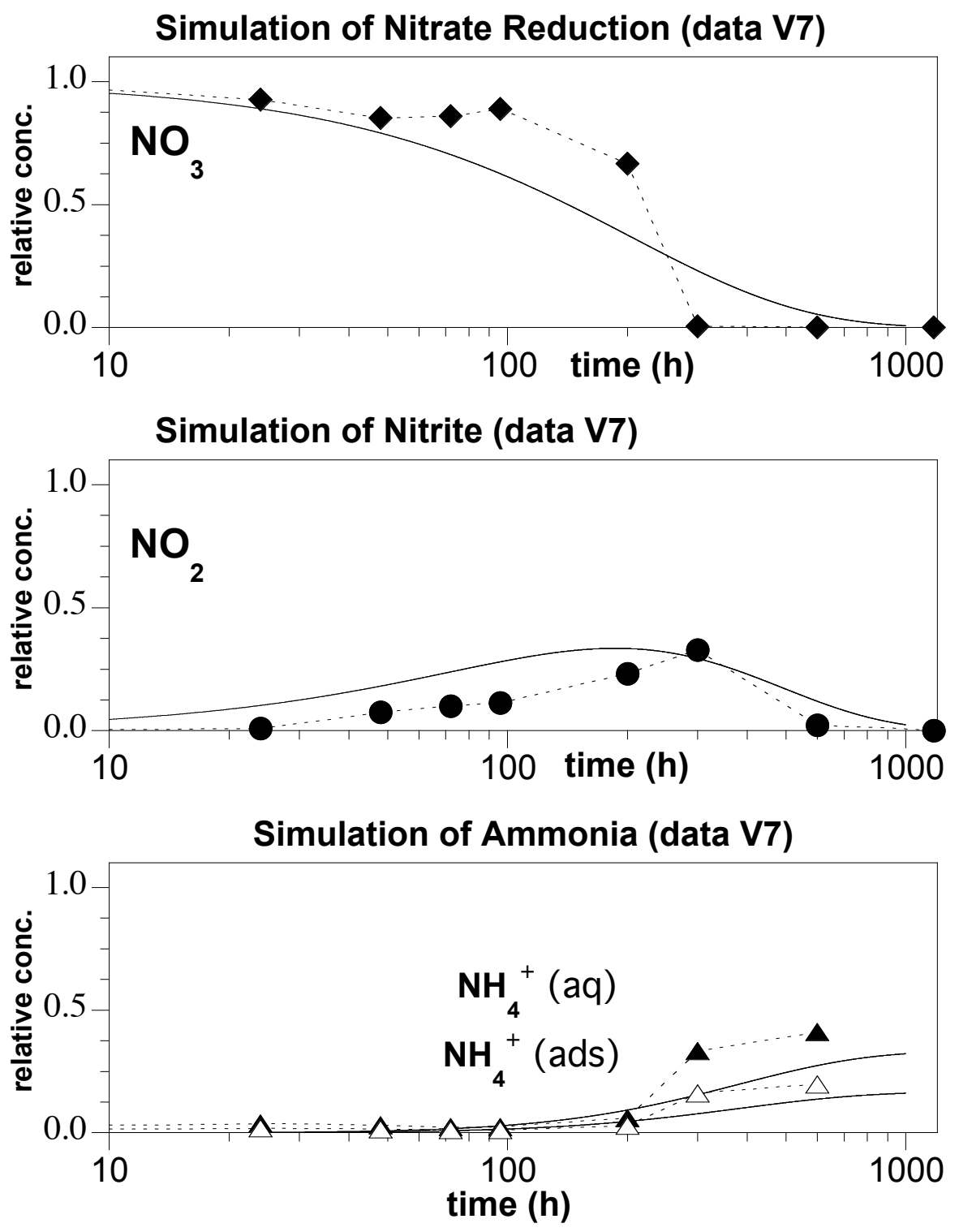

Figure 3. Nitrate reduction in a batch experiment and reaction simulation fit to data. 


\subsection{Abiotic and Biotic Control of Nitrate Reduction}

Batch experiments were conducted in parallel to those previously reported (Figure 1), but with the addition of differing bactericides in order to determine if microbes play a role in the nitrate reduction reactions. Separate experiments were conducted with treatments that included $1 \%$ gluteraldehyde (V8a), $2 \mathrm{mM}$ ammonium molybdate tetrahydrate (V8b), and $6 \mathrm{mM}$ sodium 2-bromoethanesulfonate (V8c), and Co-60 gamma radiation (V8d).

There was interference for $\mathrm{N}$ product identification for the gluteraldehyde and molybdate (results in Appendix A). In addition, the gamma radiation dose of the sediment (calculated to disrupt cell membranes, $48 \mathrm{~h}$ treatment) oxidized the sediment. Valid results are with the sulfonate treatment (Figure 4), which showed nearly identical nitrite and ammonia production rates to the experiment with no bactericide (Figure 1). Therefore, it appears that microbes do not play a significant role in these nitrate transformation reactions. This is unfortunate, since if microbes were part of the nitrate reduction process, there would be additional electron transfer reactions involved and the abiotic ISRM barrier would be less influenced.

The possibility of ammonia loss to the gas phase was also investigated as there is headspace in these batch experiments. For comparison, the dimensionless Henry's Law coefficient for ammonia is $6.6 \mathrm{E}-4$, for TCE is 0.37 , and for carbon tetrachloride is 1.1 . Calculations showed that due to the low vapor pressure of ammonia, loss to the gas phase is insignificant $(<0.02 \%$, Figure 5).

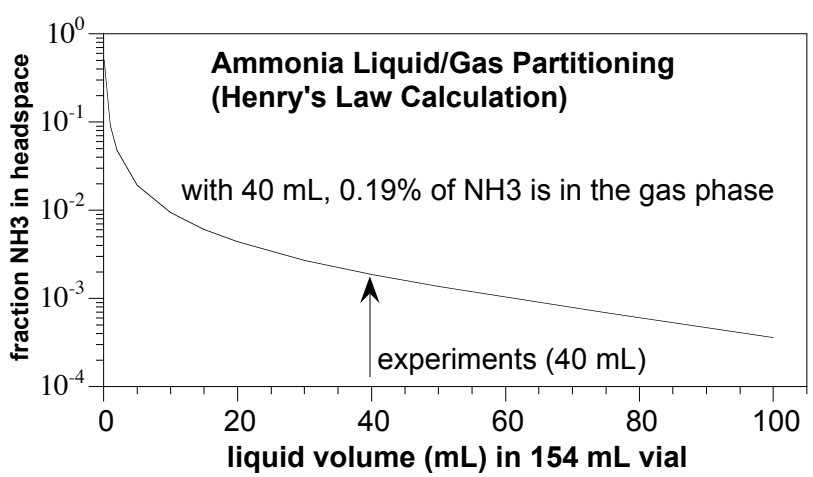

Figure 5. Calculated partitioning of ammonia to the gas phase in $154 \mathrm{~mL}$ batch vials. 


\subsection{Influence of Chromate and Oxygen on the Nitrate Reduction Rate}

Both dissolved oxygen and chromate should thermodynamically be reduced before nitrate, so the presence of either of these reductants should slow the nitrate reduction rate. Separate batch experiments was conducted in parallel with experiment V7 (Figure 1) in which both nitrate and chromate were present as electron acceptors, or nitrate and dissolved oxygen were present as electron acceptors. In the chromate/nitrate experiment, $8 \mathrm{~g}$ of reduced sediment were mixed with $40 \mathrm{~mL}$ of water containing $10 \mathrm{mg} / \mathrm{L}$ nitrate (total $0.013 \mathrm{meq} \mathrm{e}-)$ and $2 \mathrm{mg} / \mathrm{L} \mathrm{Cr}$ as chromate $(0.0046 \mathrm{meq} \mathrm{e}-)$. The sediment had an estimated 160 meq e-. While the hypothesis is correct from a thermodynamic basis, because the electron acceptor quantities were so small relative to the donor capacity of the sediment, there was no influence on the nitrate reduction rate. Results (Figure 6a) show that the nitrite and ammonia production was nearly identical to the experiment without chromate (Figure 1). Chromate was all reduced within the first hour. A similar type of experiment was conducted in a 1-D column, as described in a following section (Figure 8).

In the dissolved oxygen/nitrate experiment, there was slightly more equivalents of oxygen present than nitrate. Although the results are similar to previous results, there was a small decrease in the nitrate reduction rate (Figure 6b) compared to the experiment with only nitrate (Figure 1).
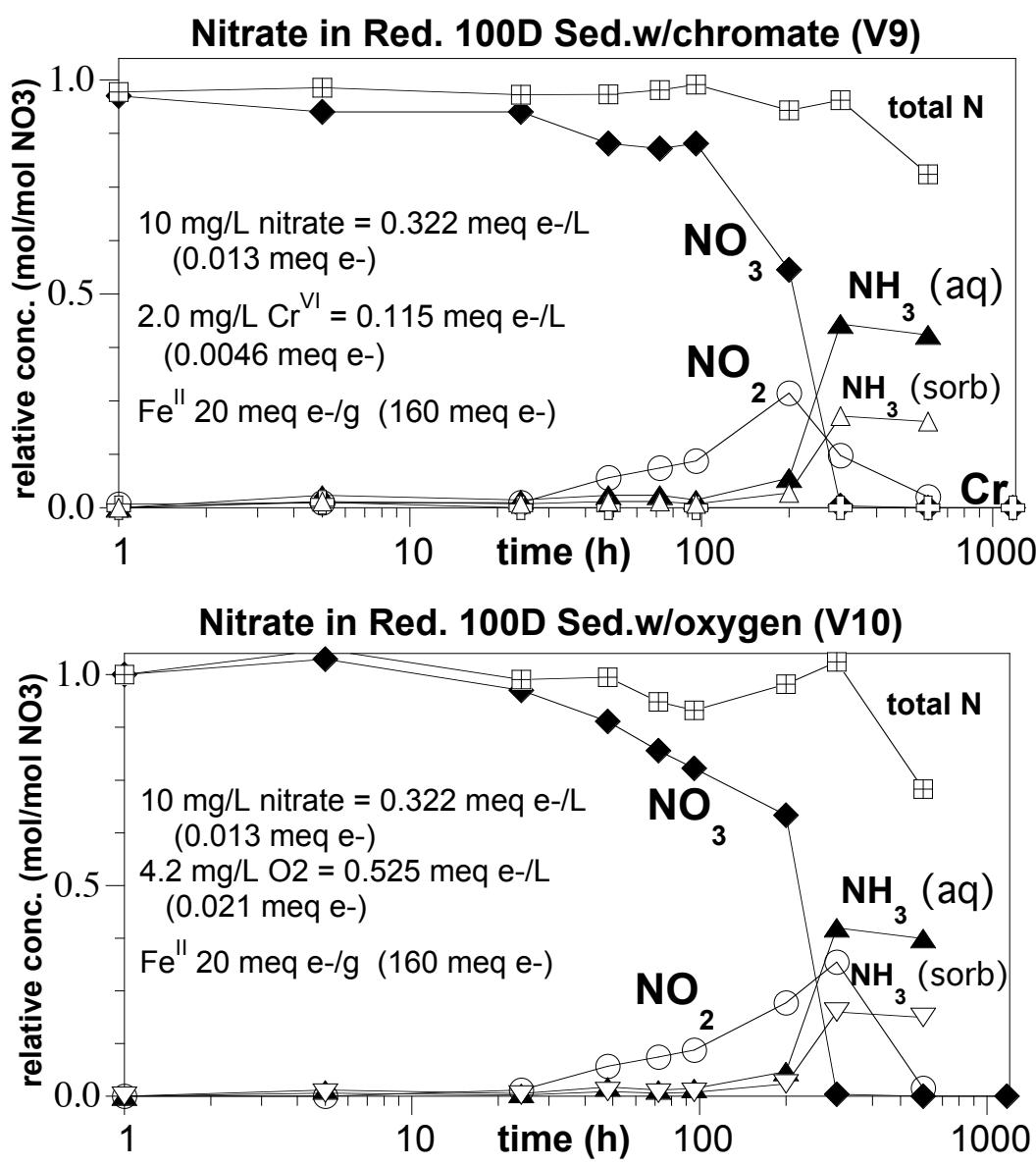

Figure 6. Nitrate reduction in a batch experiment with dithionite-reduced 100D composite sediment $(<4 \mathrm{~mm})$ in the presence of: a) chromate, and b) dissolved oxygen. 


\subsection{Influence of Flow on the Nitrate Reduction Rate}

A series of three column experiments were conducted with a reduced 100D sediment column and $60 \mathrm{ppm}$ nitrate injection at differing residence times in the column: a) 10 hours (experiment V13), b) $30 \mathrm{~h}$ (experiment V14), and $100 \mathrm{~h}$ (experiment V15). Conducting the experiments at different flow rates should provide the most robust (and field applicable) reaction rates. Column experiments are similar to the field soil/water ratio of the field and the nitrate concentration is at the $60 \mathrm{ppm}$ observed in the field. Small columns, however, do not incorporate spatial heterogeneities (i.e., high-K/low-K zones) that are observed in the field. The "residence" time is the amount of time a non-sorbing compound (like nitrate) is in contact with the sediment.

Results showed that with a $10 \mathrm{~h}$ residence time (Figure 7a), the average nitrite concentration was $2.4 \%$ and average ammonia was $1.1 \%$ (of influent nitrate). Increasing the residence time allowed for more of the slow reduction reactions to take place, so with a $30 \mathrm{~h}$ residence time, the average nitrite concentration was $4.7 \%$ and average ammonia was $6.6 \%$. With a $100 \mathrm{~h}$ residence time the reaction product concentrations increased further (average nitrite $12.3 \%$ and average ammonia was $16.1 \%$. The average nitrite production rate (i.e., using the nitrite data) was $416 \pm 109 \mathrm{~h}$ (as a half life), whereas the average ammonia production rate was $448 \pm$ $153 \mathrm{~h}$ (as a half-life). Values were the same as observed in batch experiments at the same ferrous iron/nitrate ratio, so both batch and column data were used in the same plots (Figure 2) to determine accurate reaction rates.

The presence of dissolved oxygen had no influence on the nitrate reduction rate, as shown by comparison of a column experiment with $60 \mathrm{mg} / \mathrm{L}$ nitrate injection only (Figure 7c) to a column experiment with $60 \mathrm{mg} / \mathrm{L}$ nitrate and $8.4 \mathrm{mg} / \mathrm{L}$ dissolved oxygen injection (Figure 7d).
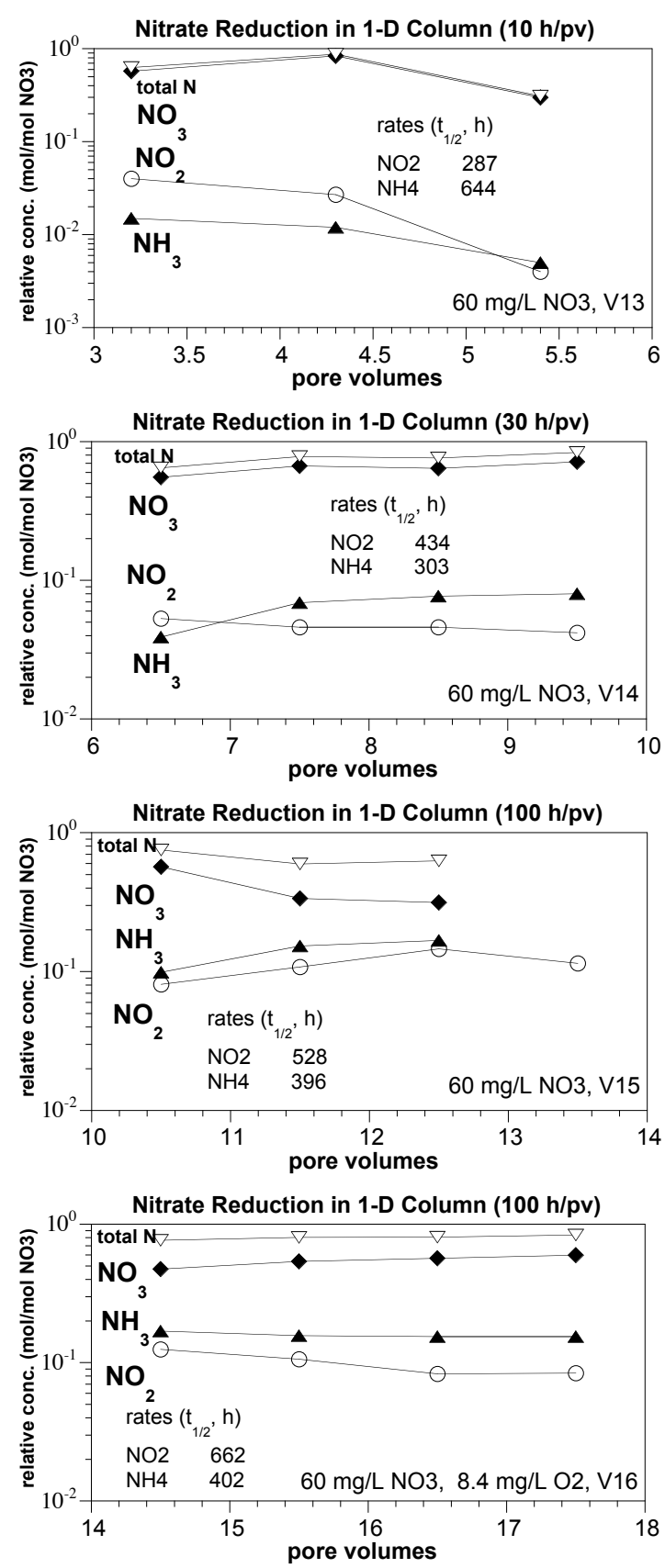

Figure 7. Nitrate reduction in 1-D columns at different flow rates: a) $10 \mathrm{~h}$ residence time, b) $30 \mathrm{~h}$ residence time, c) $100 \mathrm{~h}$ residence time, and d) $100 \mathrm{~h}$ residence time (with dissolved oxygen). 


\subsection{Influence of Barrier Longevity on Nitrate and Chromate Reduction}

Previous batch and column experiments have shown what rates of nitrate, nitrite, and chromate reduction that can be achieved in dithionite-reduced 100D Area sediments. These rates are applicable to zones that received a high dithionite treatment. Over time as the ferrous iron in the reduced sediment is oxidized, the degradation rates should be slower. This has essentially been demonstrated with the graph of ferrous iron/nitrate ratio versus nitrate reduction rate (Figure 2). In this case, as sediments become oxidized, the ratio decreases, so the nitrate degradation rate decreases (Figure 2a). Nitrite production and ammonia production rates were essentially not functions of the ferrous iron/nitrate ratio (Figure 2b, 2c), as long as there was sufficient ferrous iron to promote the reaction (i.e., ratio $>20$ ). Eventually as the ferrous iron concentration decreases sufficiently, it is expected that all of the nitrate reduction reactions will decrease. Detailed plots of each column experiment are in Appendix B, with summary plots shown.

A series of five column experiments were conducted with dithionite-reduced 100D sediment that was oxidized for 250 pore volumes, and periodic measurements of $\mathrm{N}$-compounds, oxygen, and chromate in order to determine reaction rate changes. In this series of experiments, dissolved oxygen was measured during most of the oxidation experiment, which was conducted at a fast flow rate to achieve a $1.0 \mathrm{~h}$ residence time (Figure $8 \mathrm{a}$ ). The dissolved oxygen data shows the oxygen consumption rate decreasing after 100 pore volumes, but some oxygen is still being consumed even at 700 pore volumes (average total consumption 210 pore volumes). The dissolved oxygen graph was replotted to 250 pore volumes to be able to compare to chromate and $\mathrm{N}$-compound data (Figure $8 \mathrm{~b}$ ).

The effluent chromate concentrations clearly showed that the chromate reduction rate is decreasing as the sediment is becoming oxidized. Chromate data in the highly reduced sediment $(<50 \mathrm{pv})$ showed a rapid reduction rate $(<0.1 \mathrm{~h})$, which increased to a $17 \mathrm{~h}$ rate at 250 pore volumes.

Nitrate reduction decreased significantly over the long-term experiment (Figure 9a), with a systematic decrease in nitrate consumption from a $12 \mathrm{~h}$ half-life (1 pv), to a $58 \mathrm{~h}$ half-life $(20 \mathrm{pv})$, to $120 \mathrm{~h}$ half-life $(240 \mathrm{pv})$. The injection concentration of nitrate was changed at $180 \mathrm{pv}$ (which changed the ferrous iron/nitrate ratio), but rates reported on the graphs are normalized for the $103 \mathrm{~mol} / \mathrm{mol}$ for comparison (*rates are normalized).
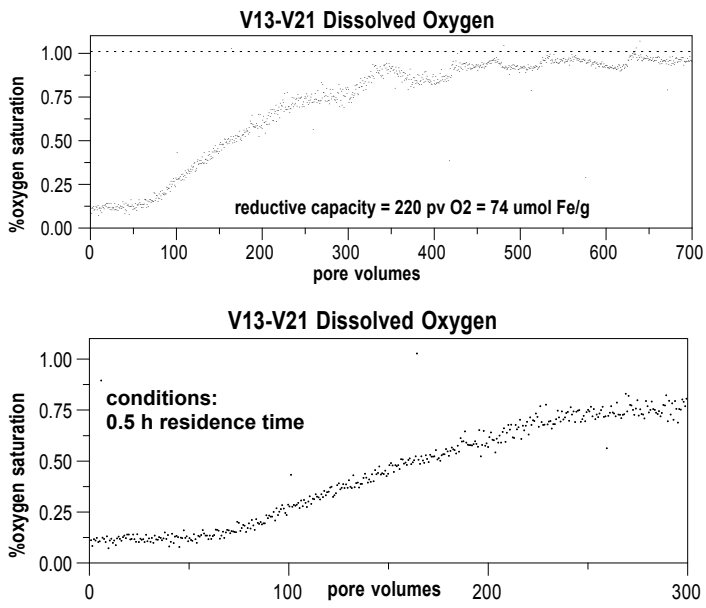

Chromate Reduction/Precipitation in 100D Sediment

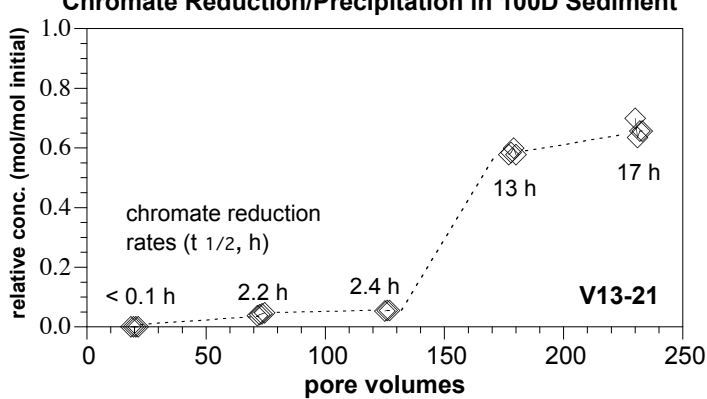

Figure 8. Long term oxidation column experiment with a reduced sediment column in which $2 \mathrm{mg} / \mathrm{L}$ chromate, $8.4 \mathrm{mg} / \mathrm{L} \mathrm{O}$, and $60 \mathrm{mg} / \mathrm{L}$ nitrate was injected. Effluent concentration of dissolved oxygen $(a, b)$, and chromate (c) shown. 
Nitrite production (Figure 9b) decreased slightly for the first 120 pore volumes (half life $287 \mathrm{~h}$ at $2 \mathrm{pv}$; $383 \mathrm{~h}$ at $120 \mathrm{pv}$ ), but then rates calculated from the data in which $18 \mathrm{mg} / \mathrm{L}$ was injected (180 pv to $250 \mathrm{pv}$ ) showed more rapid rates. Overall, little change in the nitrite concentration was observed, which is similar to batch observations at different ferrous iron/nitrate ratios (Figure 2b). This may be indicative of there still being sufficient ferrous iron to produce nitrite.

Ammonia production in the column experiments (Figure 9c) showed a systematic decrease over the 250 pore volumes. Due to adsorption of ammonia (which is assumed to be rapid), the total ammonia produced is likely $15 \mathrm{x}$ greater than the aqueous concentrations measured. Calculated ammonia production rates decreased from $644 \mathrm{~h}$ half-life $(2 \mathrm{pv})$ and $207 \mathrm{~h}(20 \mathrm{pv})$ to $2660 \mathrm{~h}$ half-life (250 pv).

In general, dissolved oxygen, chromate, and nitrate reduction slowed as the ferrous iron in the dithionite-reduced sediment became oxidized.
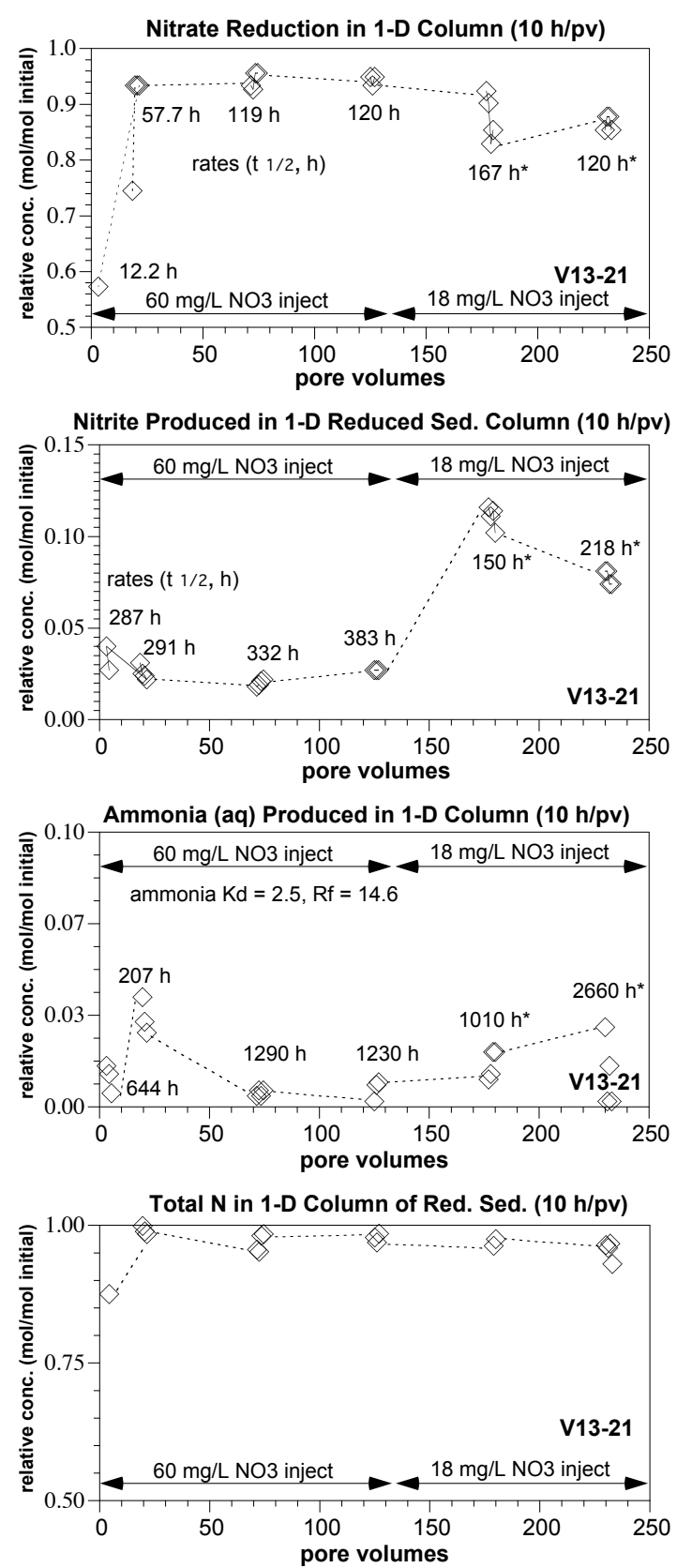

Figure 9. Long term oxidation column experiment with a reduced sediment column in which $2 \mathrm{mg} / \mathrm{L}$ chromate, $8.4 \mathrm{mg} / \mathrm{L} \mathrm{O}$, and $60 \mathrm{mg} / \mathrm{L}$ nitrate was injected. Effluent concentration of: a) $\mathrm{NO}_{3}$, b) $\mathrm{NO}_{2}$, c) $\mathrm{NH}_{4}^{+}$, and d) total $\mathrm{N}$ shown. 


\subsection{Summary}

Groundwater nitrate concentrations upgradient of the Hanford 100D Area in situ redox manipulation (ISRM) barrier are about $60 \mathrm{mg} / \mathrm{L}$ over a wide spread area (Figure 10). This study was initiated to investigate what influence nitrate degradation within the reduced sediment barrier, if occurring, on the barrier longevity. Batch and 1-D column experiments have shown that nitrate is being slowly reduced to nitrite and ammonia. There is a possibility that $\mathrm{N}_{2}$ is also being generated, based upon nitrogen mass balance of other measured species (i.e., $\mathrm{N}_{2}$ was not measured). Experiments with and without bactericides clearly showed that these nitrogen reduction reactions are abiotic. Nitrate reduction to nitrite consumes two moles of electrons (two moles of ferrous iron in the sediment). Although this indicates that the reaction rate should be secondorder with respect to ferrous iron, the observed nitrate reduction rate is 0.67 order in iron concentration, which indicated the reaction is partially controlled by some other mechanism such as diffusion of ferrous iron on the sediment surface or within minerals. Experiments also showed that nitrite production and ammonia production were nearly independent of the ferrous iron concentration (with ferrous iron/nitrate $>20$ ), showing major reaction rate control by something other than the theoretical chemical reaction. This information is useful in determining reaction rates at different ferrous iron/nitrate ratios.

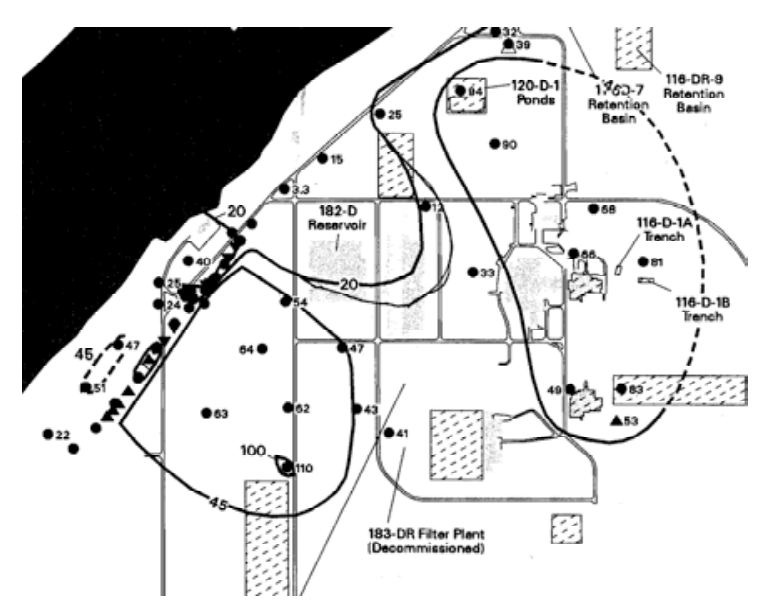

Figure 10. Hanford 100D Area ground water nitrate concentrations in 2004. The ISRM barrier is in the left center.

Nitrogen species transformation reaction rates determined in laboratory experiments covered a range of ferrous iron/nitrate ratios such that the data can be used to predict rates that should occur in field scale conditions of the high sediment/water ratios and at $16^{\circ} \mathrm{C}$. Field scale estimates of the reaction rates for $100 \%$ reduced sediment are:

$$
\begin{aligned}
& \text { nitrate degradation }\left(16^{\circ} \mathrm{C}\right)=202 \pm 50 \mathrm{~h} \text { (half-life) } \\
& \text { nitrite production }\left(16^{\circ} \mathrm{C}\right)=850 \pm 300 \mathrm{~h} \text { (half-life) } \\
& \text { ammonia production }\left(16^{\circ} \mathrm{C}\right)=650 \pm 300 \mathrm{~h} \text { (half-life) }
\end{aligned}
$$

Of greatest significance for the barrier longevity is ammonia production, which requires a total of 8 moles of electrons (ferrous iron) per mole of nitrate consumed. The ammonia production rate decreases as the barrier becomes oxidized (i.e., at a smaller ferrous iron/nitrate ratio). 
Calculation of the 100D Area reductive capacity requires both mass balance considerations of the electron donor (ferrous iron) and electron acceptors (dissolved oxygen, chromate, and nitrate), as well as reaction rates. As described in the background section, dissolved oxygen and chromate reduction rates are rapid (minutes to hours), so are essentially at equilibrium in the field scale residence times of the barrier of 30 days for a $30-\mathrm{ft}$ wide barrier (i.e., assuming $1.0 \mathrm{ft} /$ day groundwater flow velocity). In contrast, ammonia production in 30 days $(720 \mathrm{~h})$ is only partially completed, given the $650 \mathrm{~h}$ half-life for ammonia production. For $100 \%$ reduced sediment and a $1 \mathrm{ft} /$ day groundwater velocity, the 100D Area reductive capacity is reduced from 160 pore volumes (if no nitrate) to 85 pore volumes (with $60 \mathrm{mg} / \mathrm{L}$ nitrate), as shown in Figure 11, solid line. Fast flow channels that are known to exist have shorter residence times in the reductive sediment barrier. For example, at $3 \mathrm{ft} / \mathrm{day}$ (residence time 10 days in the $30 \mathrm{ft}$ wide barrier), the barrier capacity is now 125 pore volumes. Alternatively, aquifer locations with slower flow will provide sufficient additional residence time to consume additional ferrous iron (i.e., reductive capacity $<90$ pore volumes).

As the barrier is slowly oxidized, the rate of nitrate reduction decreases. Typical average field scale reduction in the $100 \mathrm{D}$ Area ranges from $100 \%$ down to $10 \%$. The result is less nitrate being reduced in the partially reduced sediment, or in other words nitrate has less influence on the barrier capacity. For example, at the average groundwater velocity of $1 \mathrm{ft} /$ day, $100 \%$ reduced sediment zone will have a 85 pore volume capacity, but a $50 \%$ reduced sediment zone will have a 53 pore volume capacity (with $60 \mathrm{mg} / \mathrm{L}$ nitrate).

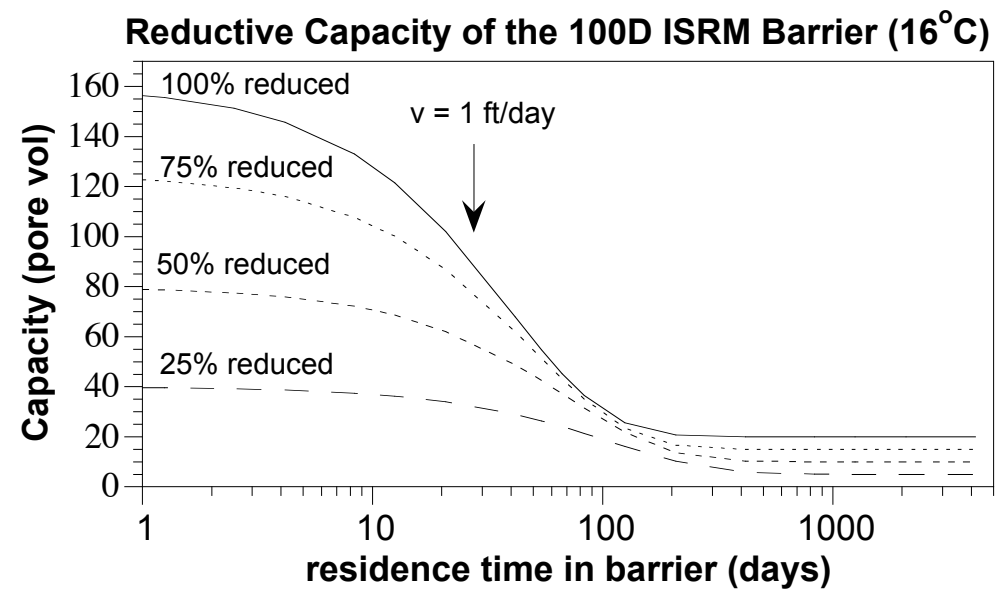

Figure 11. Influence of nitrate reduction on the 100D Area ISRM barrier longevity.

The impact of the presence of nitrate is a $50 \%$ reduction in the barrier longevity for chromate immobilization. Slower flow regions would have greater influence of nitrate reduction and faster flow regions would have less influence of the nitrate reduction. In addition, it is hypothesized that slower flow regions have greater ferrous iron capacity (i.e., finer grained sediments), which may counteract the increased nitrate reduction to some extent. A long-term column experiment in this study showed that as the barrier slowly becomes partially oxidized, the chromate concentration increases because the chromate reduction rate is slower. The column experiment in this study showed that the chromate reduction rate was $2.4 \mathrm{~h}$ or faster for 120 pore volumes, then as slow as $17 \mathrm{~h}$ by 250 pore volumes. 


\subsection{References}

Anderson LD, DB Kent, and JA Davis. 1994. "Batch Experiments Characterizing the Reduction of Cr(VI) Using Suboxic Material from a Mildly Reducing Sand and Gravel Aquifer." Environmental Science and Technology 28(1):178-185.

Balko B and P Tratnyek. 1998. "Photoeffects on the Reduction of Carbon Tetrachloride by Zero-Valent Iron.” J. Physical Chemistry 102(8):1459-1465.

Blowes D, C Ptacek, and J Jambor. 1997. "In-Situ Remediation of Cr(VI) Contaminated Groundwater Using Permeable Reactive Walls: Laboratory Studies." Environmental Science and Technology 31(12):3348-3357.

Boursiquot S, M Mullet, and J Ehhrhardt. 2002. "XPS Study of the Reaction of Chromium (VI) with Mackinawite (FeS)." Surface and Interface Analysis 34:293-297.

Buerge IJ and SJ Hug. 1997. "Kinetics and pH Dependence of Chromium(VI) Reduction by Iron(II)." Environmental Science and Technology 31(5):1426-1432.

Chao TT and L Zhou. 1983. "Extraction Techniques for Selective Dissolution of Amorphous Iron Oxides from Soils and Sediments." Soil Science Society of America Journal 47:225-232.

Devlin JF and D Muller. 1999. "Field and Laboratory Studies of Carbon Tetrachloride Transformation in a Sandy Aquifer Under Sulfate Reducing Conditions." Environmental Science and Technology 33(7):1021-1027.

Eary L and D Rai. 1988. "Chromate Removal from Aqueous Wastes by Reduction with Ferrous Ion." Environmental Science and Technology 22:972-977.

Fruchter JS, CR Cole, MD Williams, VR Vermeul, J Amonette, JR Szecsody, J Istok, and M Humphrey. 2000. "Creation of a Subsurface Permeable Treatment Barrier Using In-Situ Redox Manipulation." Ground-Water Monitoring Review 66-77.

Gibbs CR. 1976. "Characterization and Application of Ferrozine Iron Reagent as a Ferrous Iron Indicator." Analytical Chemistry 48(8):1197-1200.

Heron G, TH Christensen, and JC Tjell. 1994a. "Oxidation Capacity of Aquifer Sediments." Environmental Science and Technology 28:153-159.

Heron G, C Crouzet, AC Bourg, and TH Christensen. 1994b. "Speciation of Fe(II) and Fe(III) in Contaminated Aquifer Sediments Using Chemical Extraction Techniques." Environmental Science and Technology 28:1698-1705.

Jardine PM, SE Fendorf, MA Mayes, IL Larsen, SC Brooks, and WB Bailey. 1999. "Fate and Transport of Hexavalent Chromium in Undisturbed Heterogeneous Soil." Environmental Science and Technology 33(17):2939-2944.

Kim C, B Deng, E Thornton, and H Xu. 2001. "Chromium (VI) Reduction by Hydrogen Sulfide in Aqueous Media: Stoichiometry and Kinetics.” Environmental Science and Technology 35:2219-2225. 
Loyaux-Lawniczak S, P Lecomte, and J Ehrhardt. 2001. "Behavior of Hexavalent Chromium in a Polluted Groundwater: Redox Processes and Immobilization in Soils." Environmental Science and Technology 35(7):1350-1357.

Loyaux-Lawniczak S, P Refait, JJ Ehrhardt, P Lacomte, and JR Genin. 2000. "Trapping of Cr by Formation of Ferrihydrite During the Reduction of Chromate Ions by $\mathrm{Fe}(\mathrm{II})-\mathrm{Fe}(\mathrm{III})$ Hydroxysalt Green Rusts." Environmental Science and Technology 34(3):438-443.

Patterson RR and S Fendorf. 1997. "Reduction of Hexavalent Chromium by Amorphous Iron Sulfide." Environmental Science and Technology 31-2039-2044.

Pratt A, D Blowes, and C Placek. 1997. "Products of Chromate Reduction on Proposed Subsurface Remediation Material.” Environmental Science and Technology 31(9):2492-2498.

Sass BM and D Rai. 1986. "Solubility of Amorphous Chromium(III)-Iron(III) Hydroxide Solid Solutions." Inorganic Chemistry 26(14):2228-2232.

Scherer MM, BA Balko, and PG Tratnyek. 1999. "The Role of Oxides in Reduction Reactions at the Metal-Water Interface.” In: DL Sparks and T Grundl (Editors), ACS Symposium Series \#715, pp. 1-22.

Seaman JC, PM Bertsch, and L Schwallie. 1999. "In-Situ Cr(VI) Reduction within Coarse-Textured, Oxide-Coated Soil and Aquifer Systems Using Fe(II) Solutions." Environmental Science and Technology 33(6):938-944.

Stucki JW, DC Golden, and CB Roth. 1984. "Preparation and Handling of Dithionite-Reduced Smectite Suspensions." Clays and Clay Minerals 32(3):191-197.

Szecsody JE, JS Fruchter, VR Vermeul, MD Williams, and B Devary. 2005. "In Situ Reduction of Aquifer Sediments to Create a Permeable Reactive Barrier to Remediate Chromate: Bench-Scale Tests to Determine Barrier Longevity." Chapter 9, J Jacobs, ed., Groundwater Remediation of Chromate, CRC Press.

Szecsody JE, B Devary, D Girvin, J Campbell, and M McKinley. 2004a. "Fate and Transport of the Explosive CL-20 in Soils and Subsurface Sediments.” Chemosphere 56:593-610.

Szecsody JE, MD Williams, JS Fruchter, VR Vermeul, and D Sklarew. 2004b. "In Situ Reduction of Aquifer Sediments: Enhancement of Reactive Iron Phases and TCE Dechlorination." Environmental Science and Technology 38:4656-4663.

Szecsody JE, MD Williams, JS Fruchter, VR Vermeul, and J Evans. 2000. "Influence of Sediment Reduction on TCE Degradation, Remediation of Chlorinated and Recalcitrant Compounds." Book chapter, ed. G Wickramanayake, Chemical Oxidation and Reactive Barriers, p. 369-376.

Vermeul VR, MD Williams, JE Szecsody, JS Fruchter, CR Cole, and JE Amonette. 2002. "Creation of a Subsurface.” In Groundwater Remediation of Trace Metals, Radionuclides, and Nutrients, with Permeable Reactive Barriers, Academic Press.

Wehrli B. 1992. "Redox Reactions of Metal Oxides at Mineral Surfaces." In W Stumm (Editor), Aquatic Chemical Kinetics. John Wiley and Sons, New York, pp. 311-337. 
Zachara J, D Girvin, R Schmidt, and C Resch. 1987. "Chromate Adsorption on Amorphous Iron Oxyhydroxide in the Presence of Major Groundwater Ions." Environmental Science and Technology 21:589-594. 


\section{Appendix A}

\section{Batch Nitrate Reduction Experiments}




\section{Appendix A \\ Batch Nitrate Reduction Experiments}

a) Nitrate in Reduced 100D Sed. (Fe(II)/NO3 $=4.1, \mathrm{~V} 3$ )

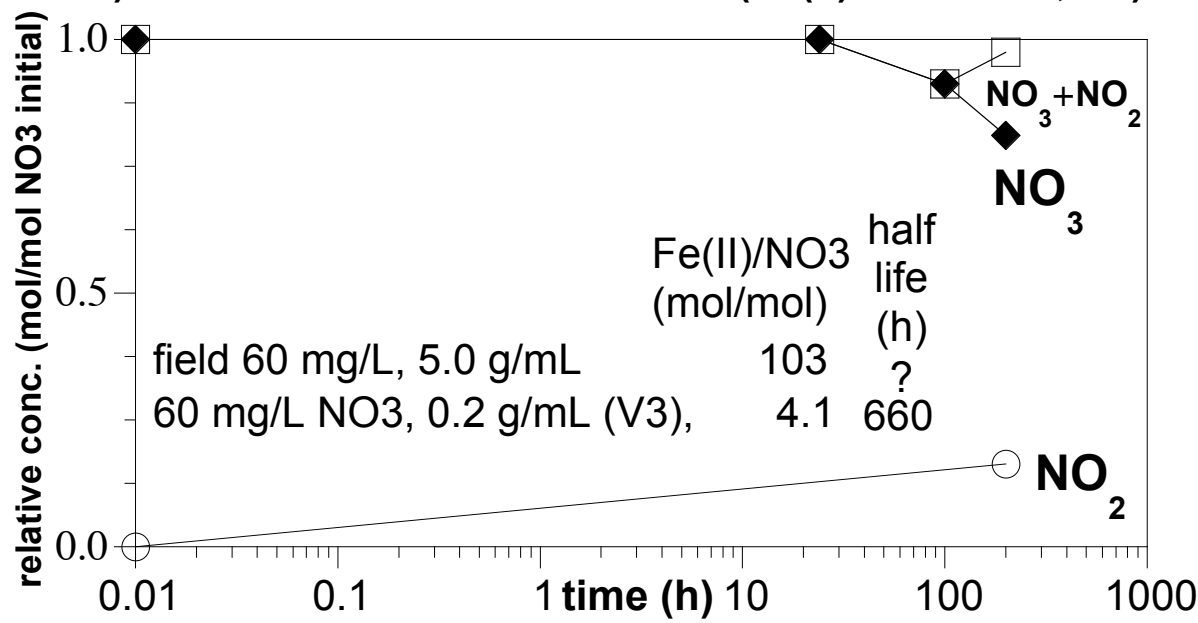

b) Nitrate in Reduced 100D Sed. (Fe(II)/NO3 $=25$, V4)

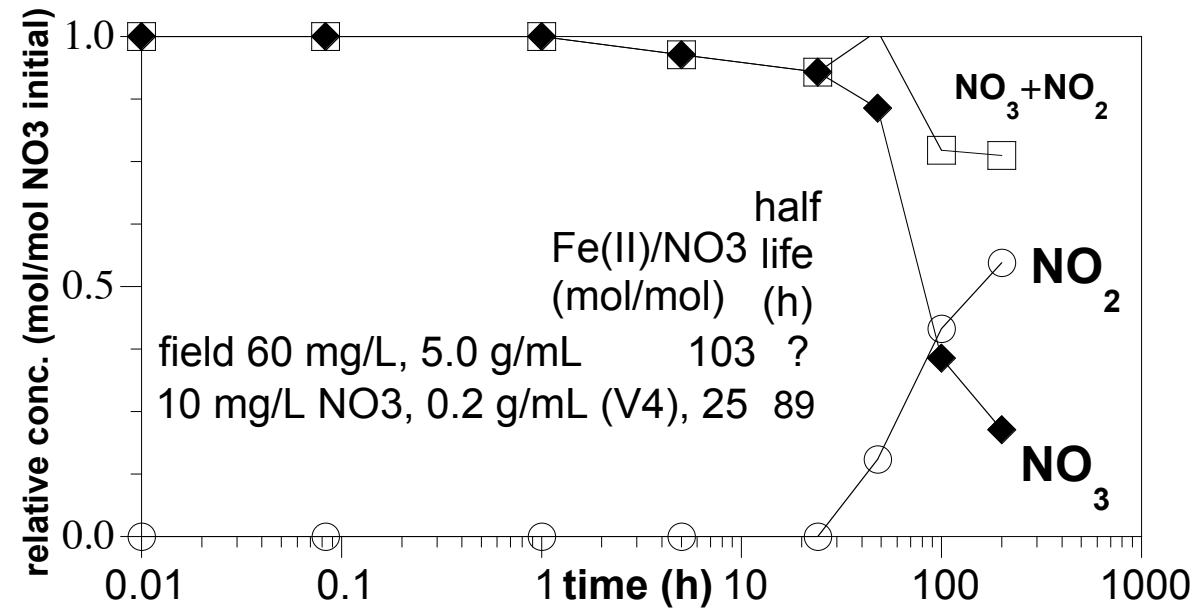

c) Nitrate in Reduced 100D Sed. (Fe(II)/NO3 $=64, \mathrm{~V} 5$ )

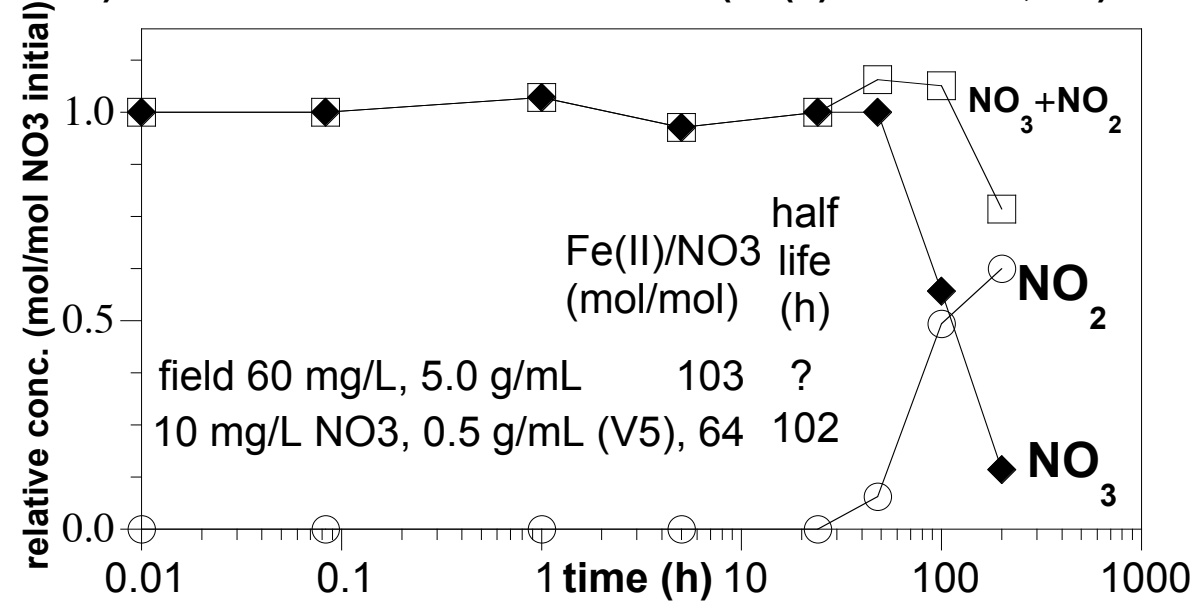



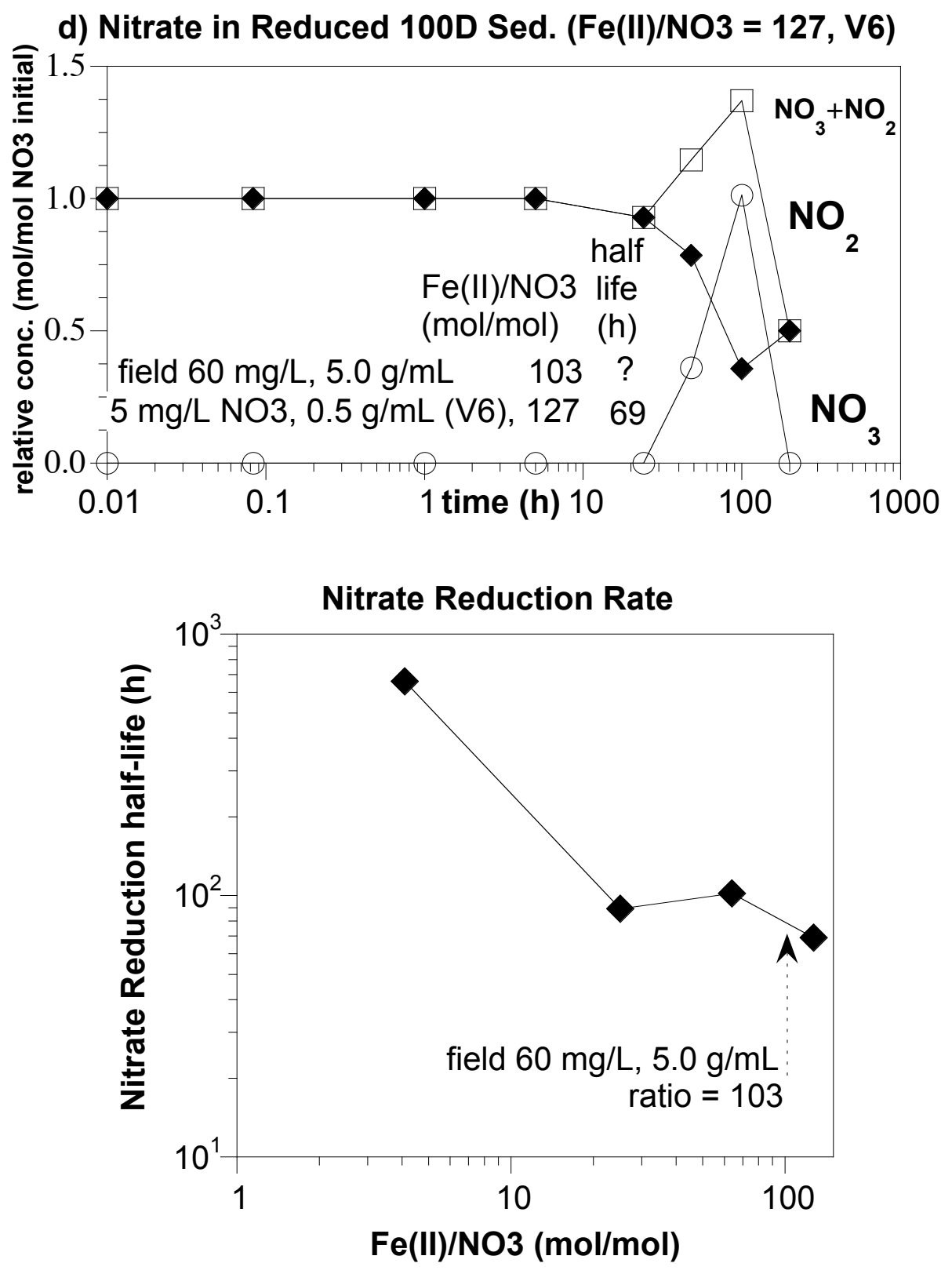
Nitrate in Reduced 100D Sed. $(\mathrm{Fe}(\mathrm{II}) / \mathrm{NO} 3=25, \mathrm{~V} 7)$
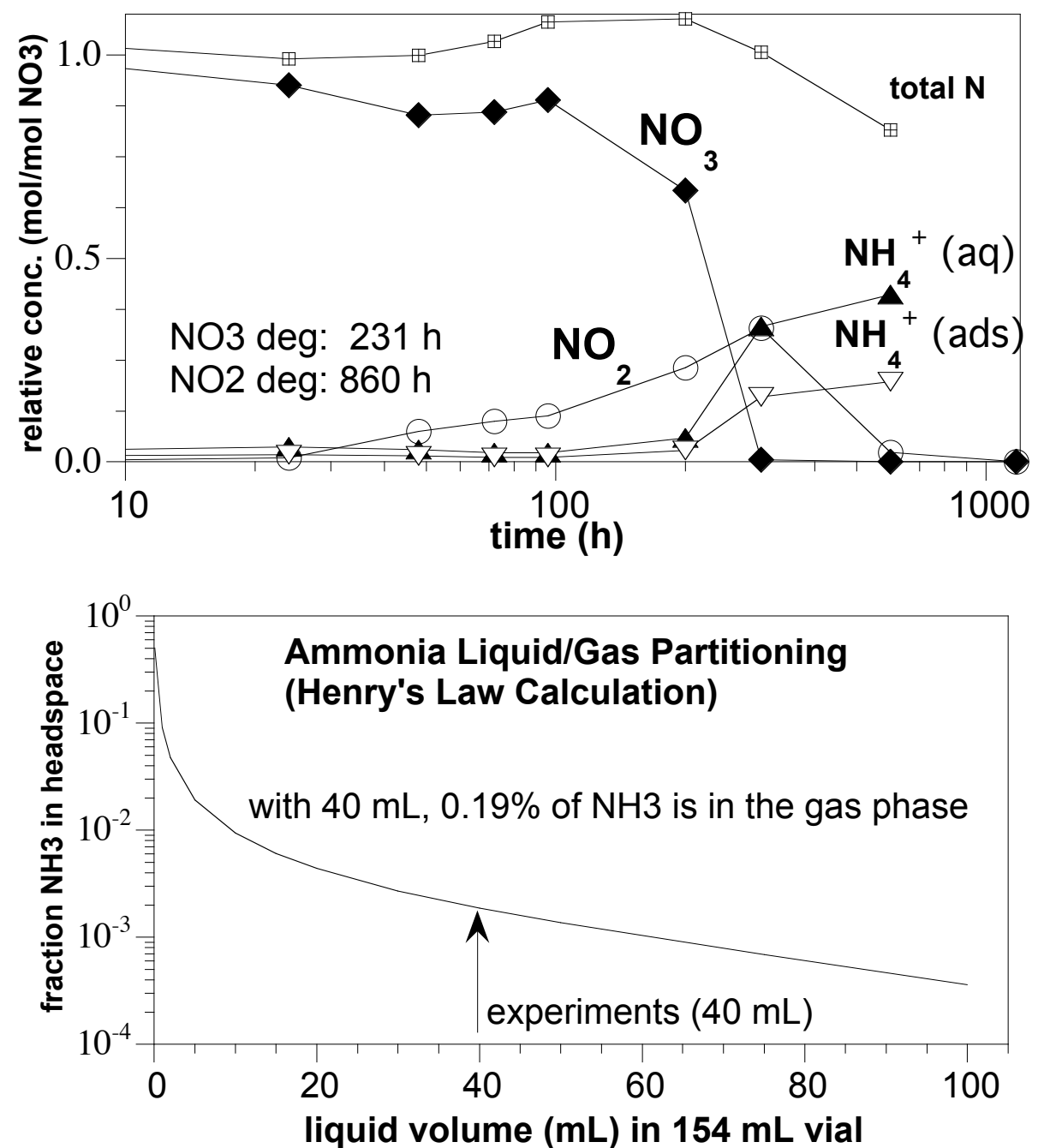

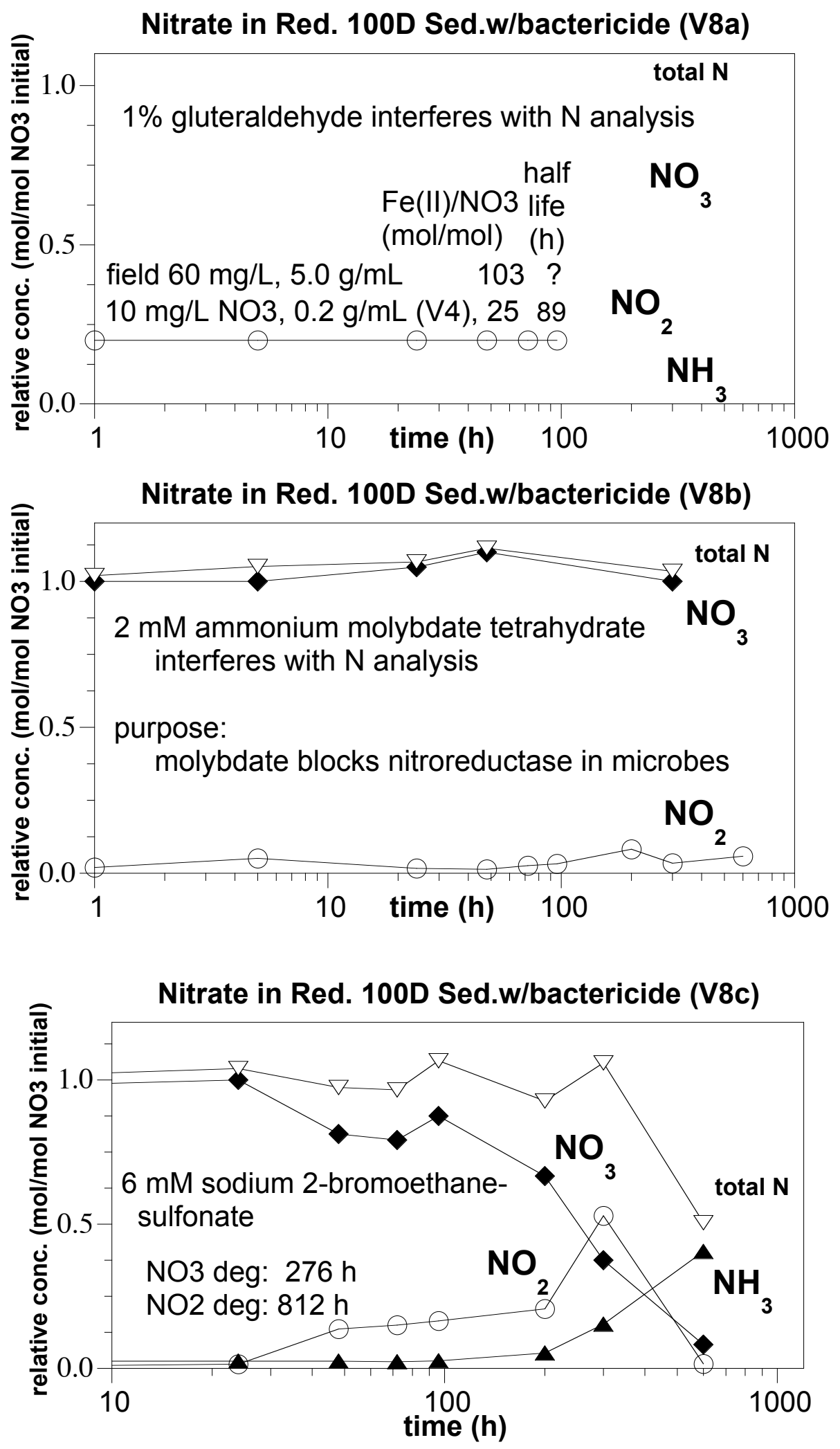

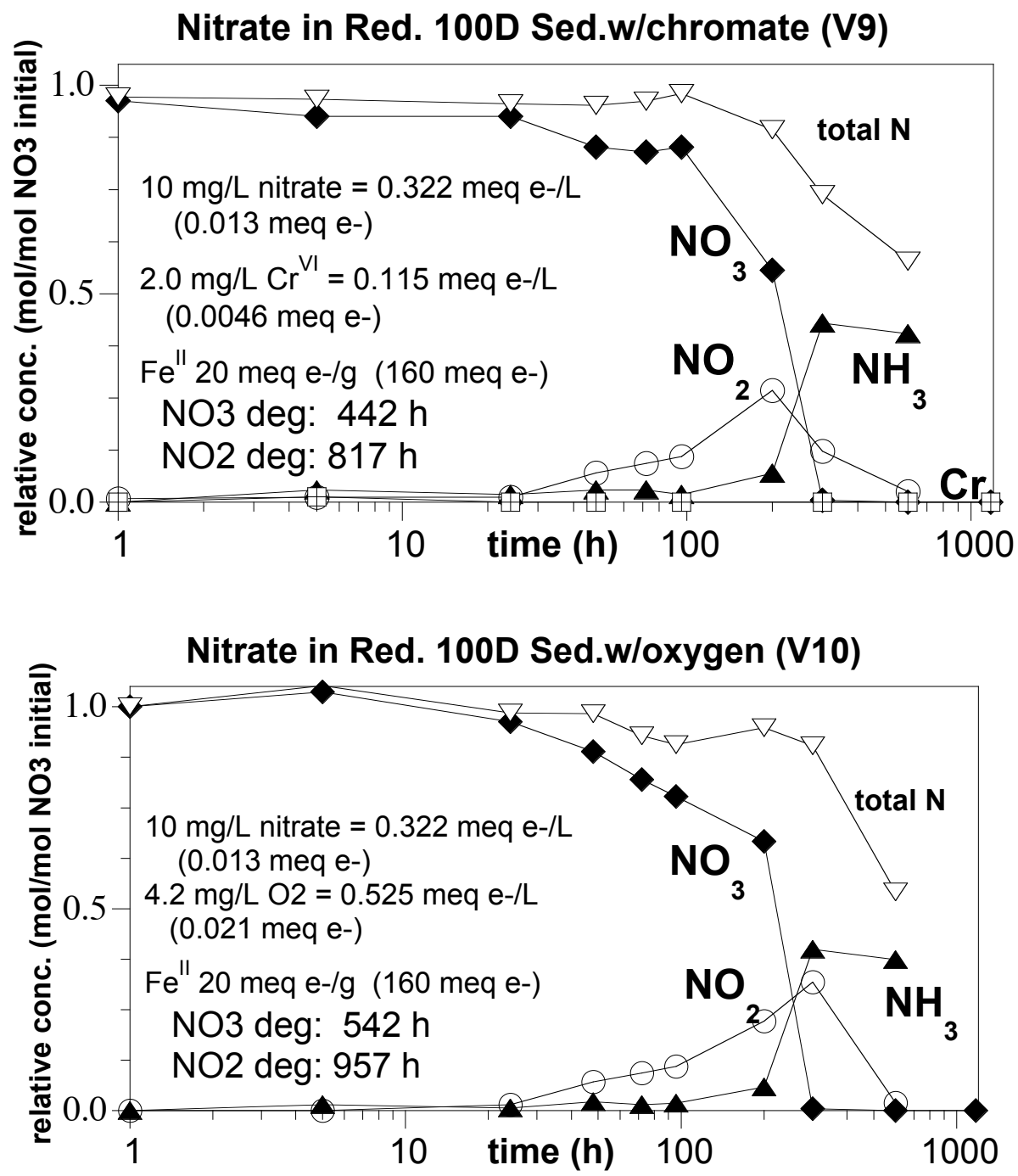
Appendix B

\section{1-D Column Nitrate Reduction Experiments}




\section{Appendix B}

\section{1-D Column Nitrate Reduction Experiments}

Nitrate 1-D Transport in Reduced 100D Sed (10 h/pv) 60 ppm NO3, no Cr, no 02 (exp. V13)

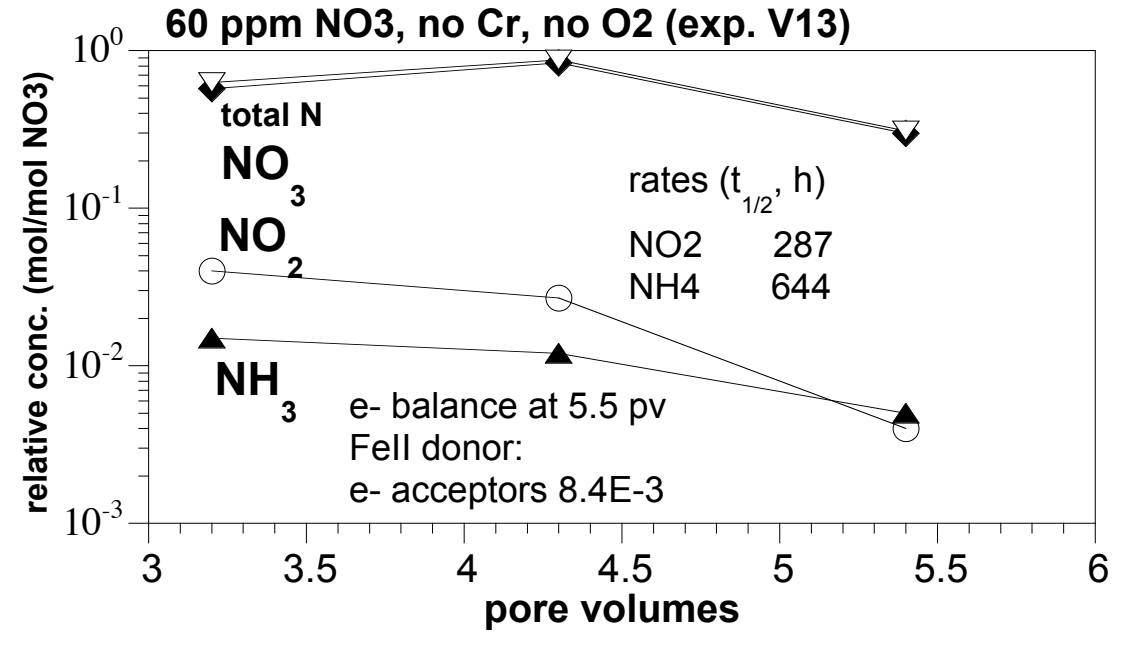

Nitrate 1-D Transport in Reduced 100D Sed (30 h/pv) 60 ppm NO3, no Cr, no $O 2$ (V14)

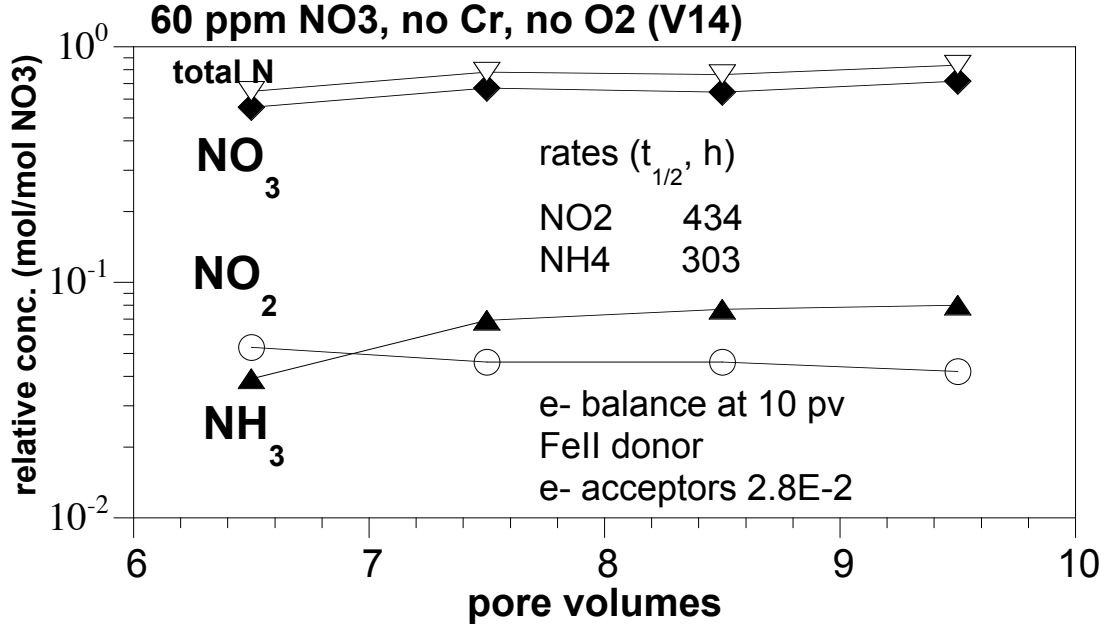

Nitrate 1-D Transport in Reduced 100D Sed (100 h/pv)

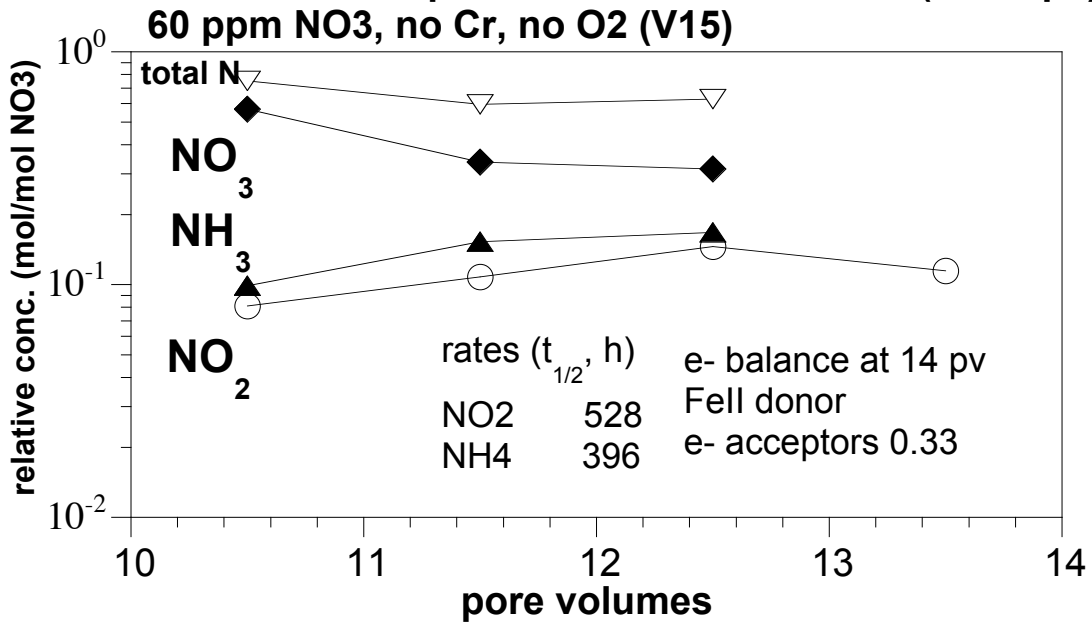

B.1 
Nitrate 1-D Transport in Reduced 100D Sed (100 h/pv)

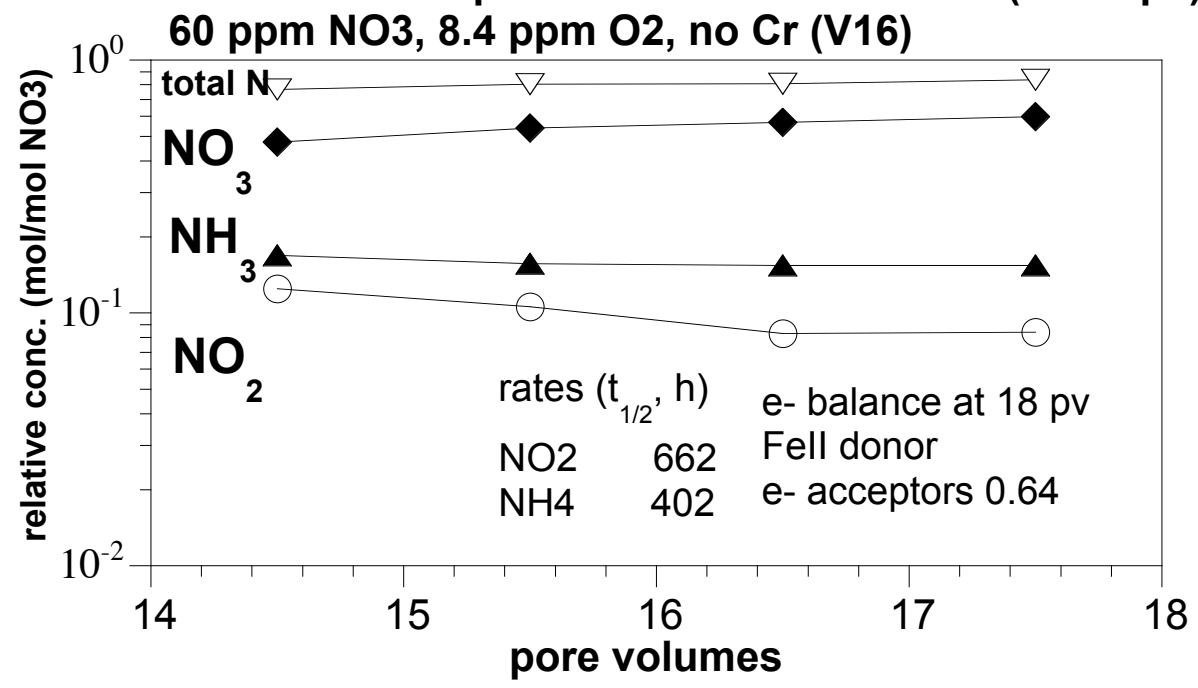

Nitrate 1-D Transport in Reduced 100D Sed (10 h/pv)

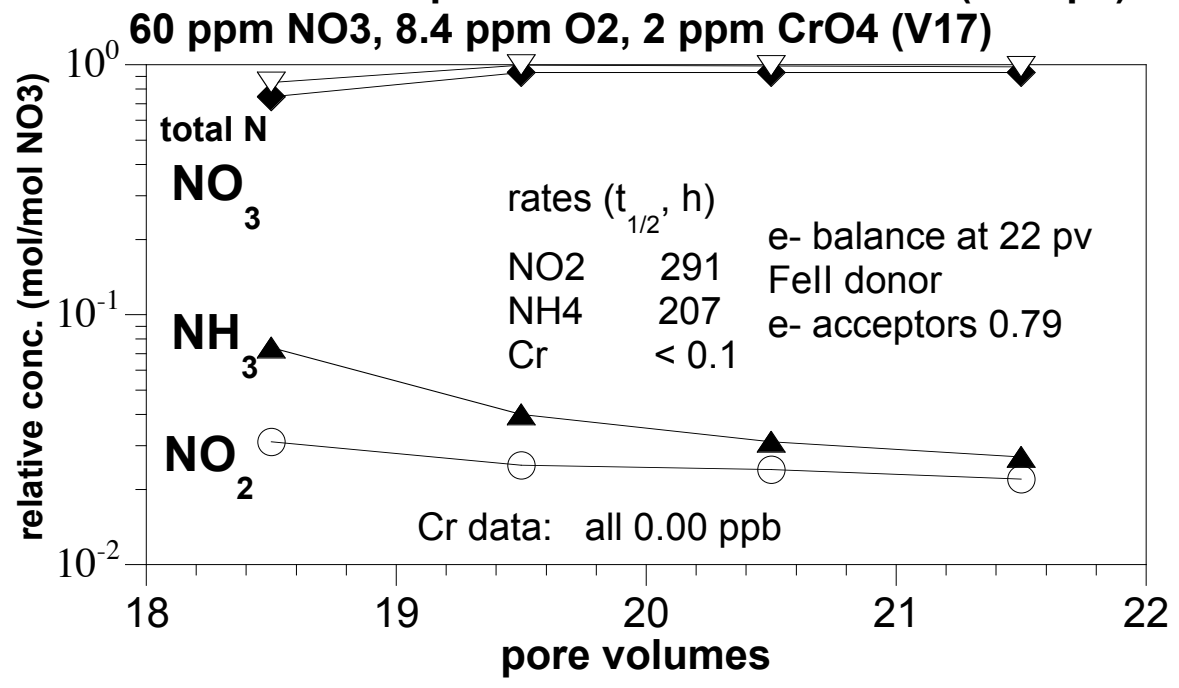

Nitrate 1-D Transport in Reduced 100D Sed (10 h/pv)

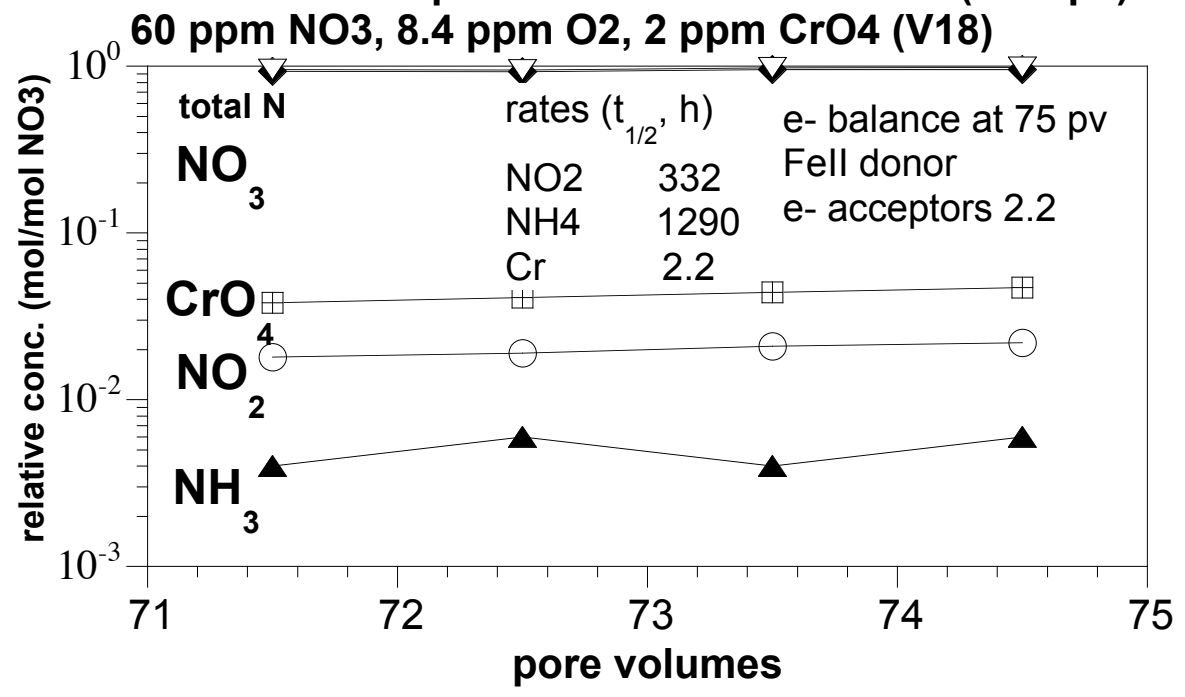

B.2 

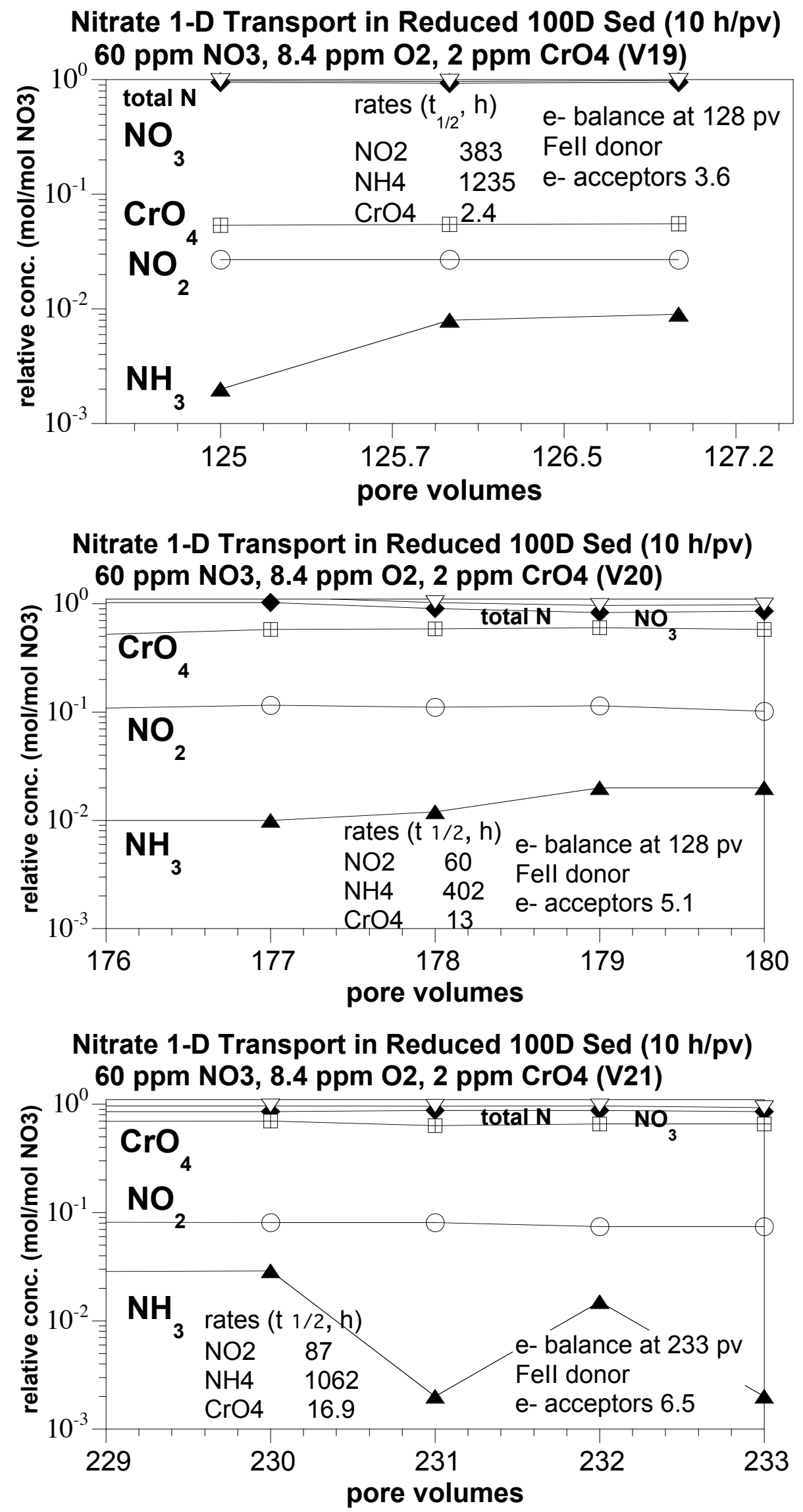

B. 3 


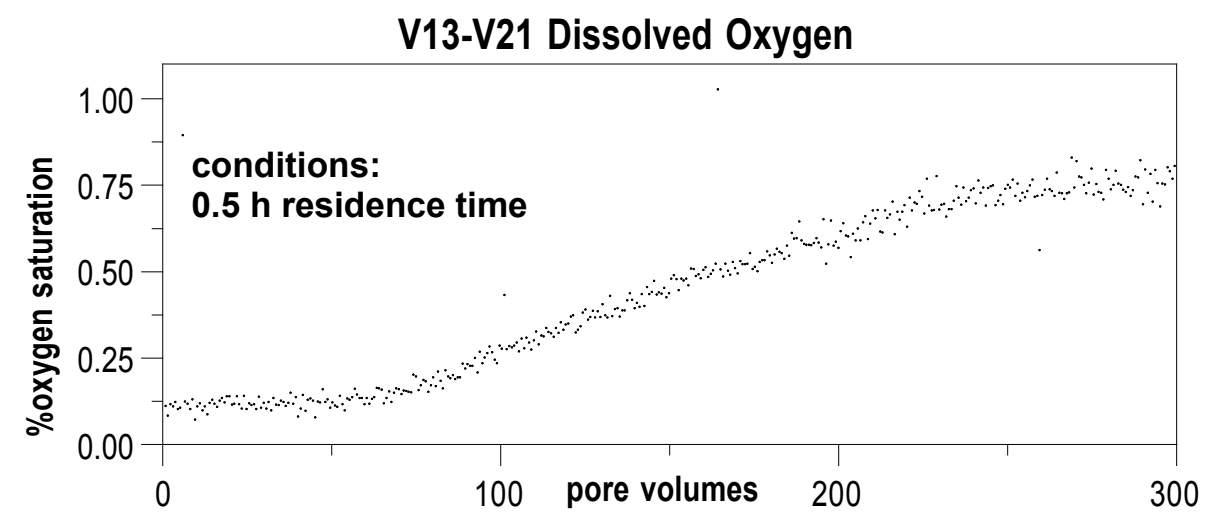

Chromate Reduction/Precipitation in 100D Sediment

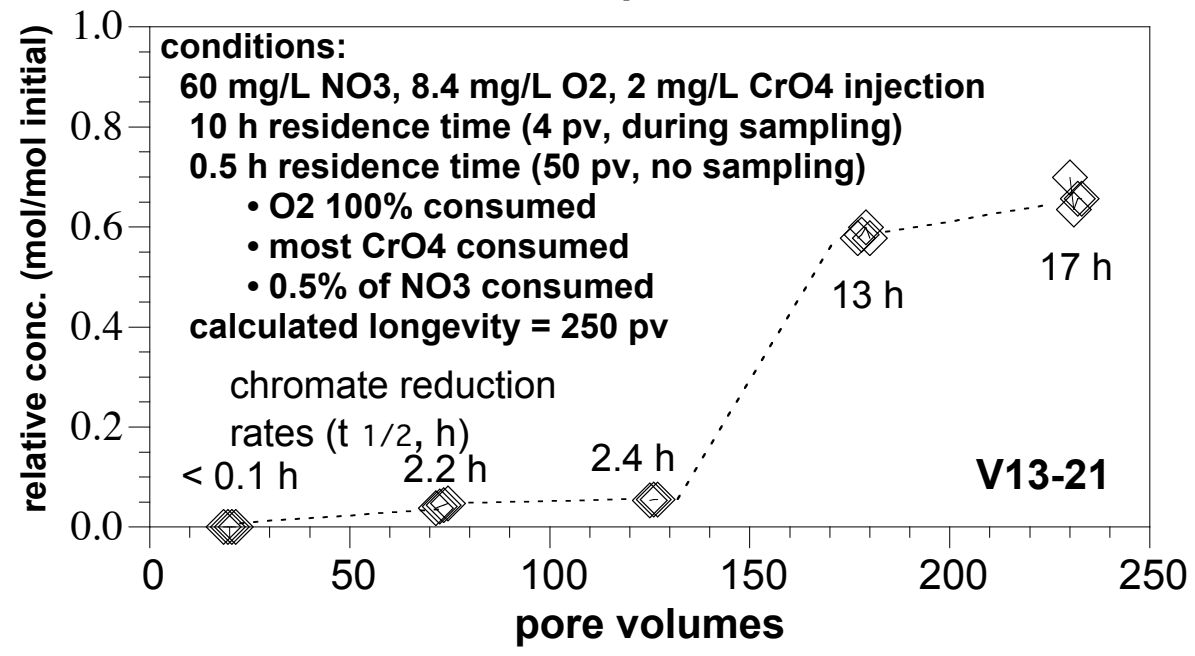

Total N in 1-D Column of Red. Sed. (10 h/pv)

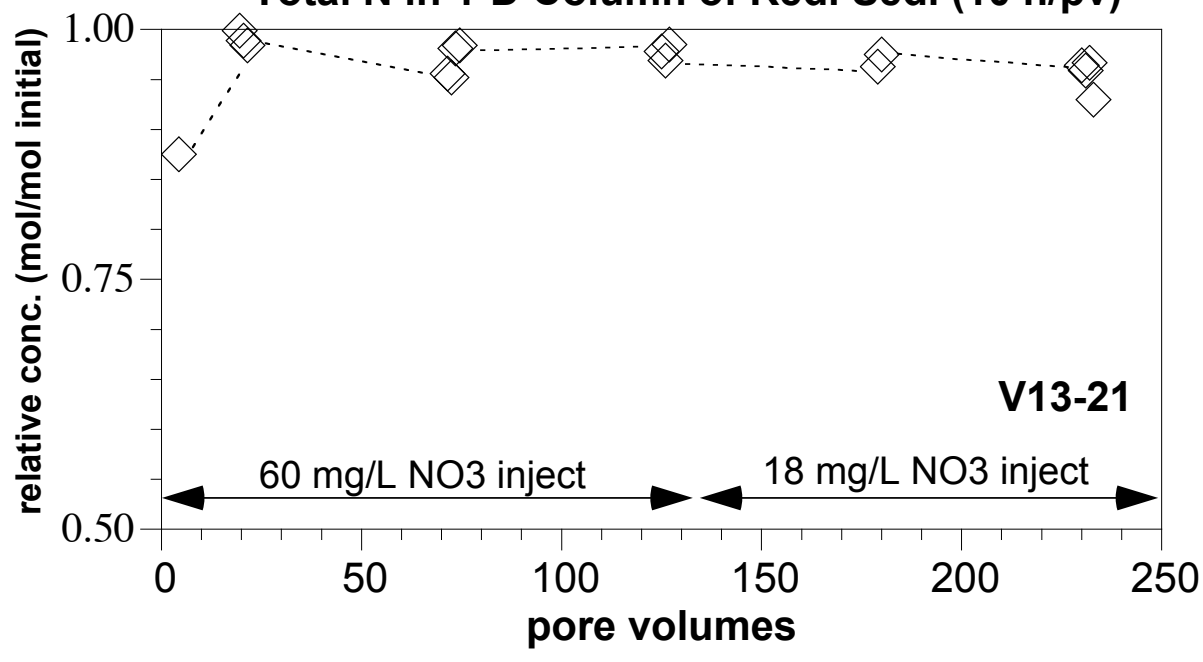




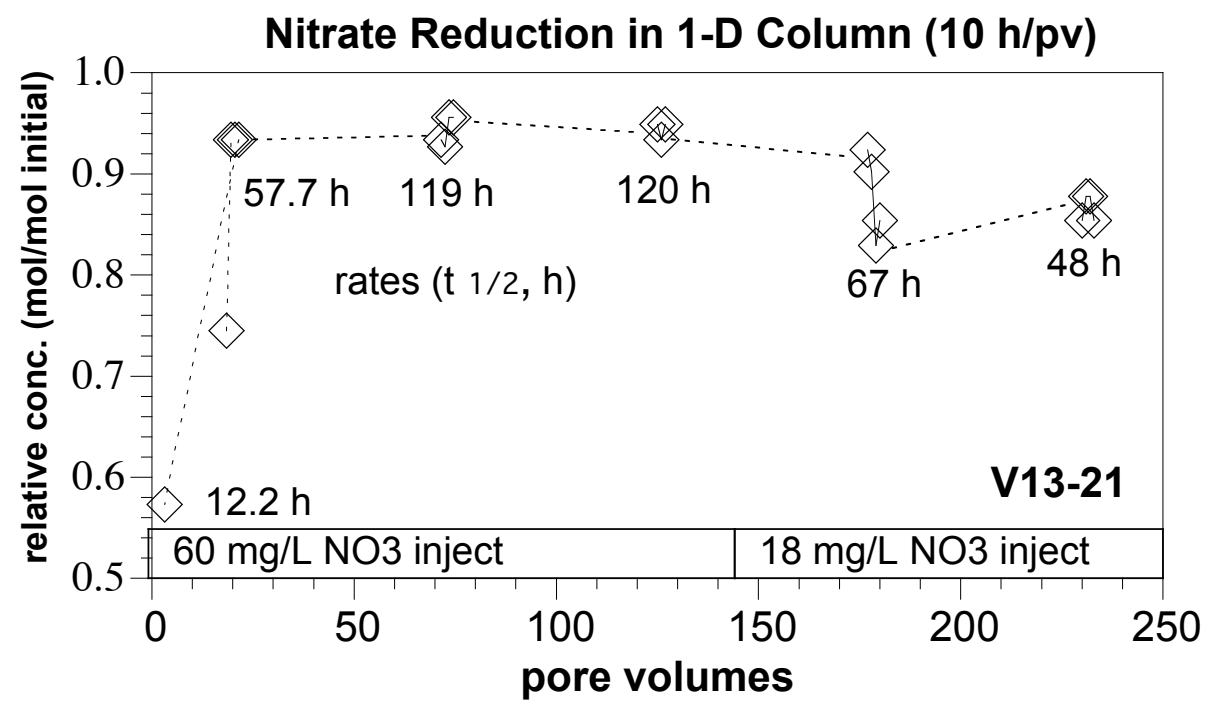

Nitrite Produced in 1-D Reduced Sed. Column (10 h/pv)

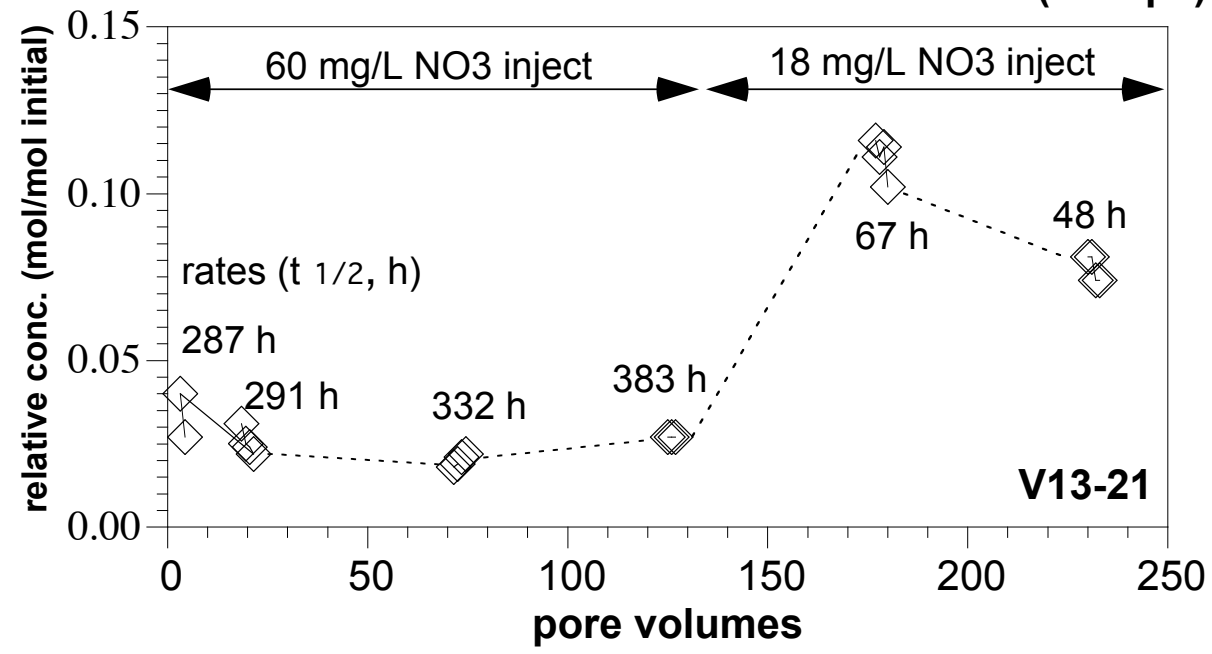

Ammonia (aq) Measured in 1-D Column of Red. Sed. (10 h/pv)

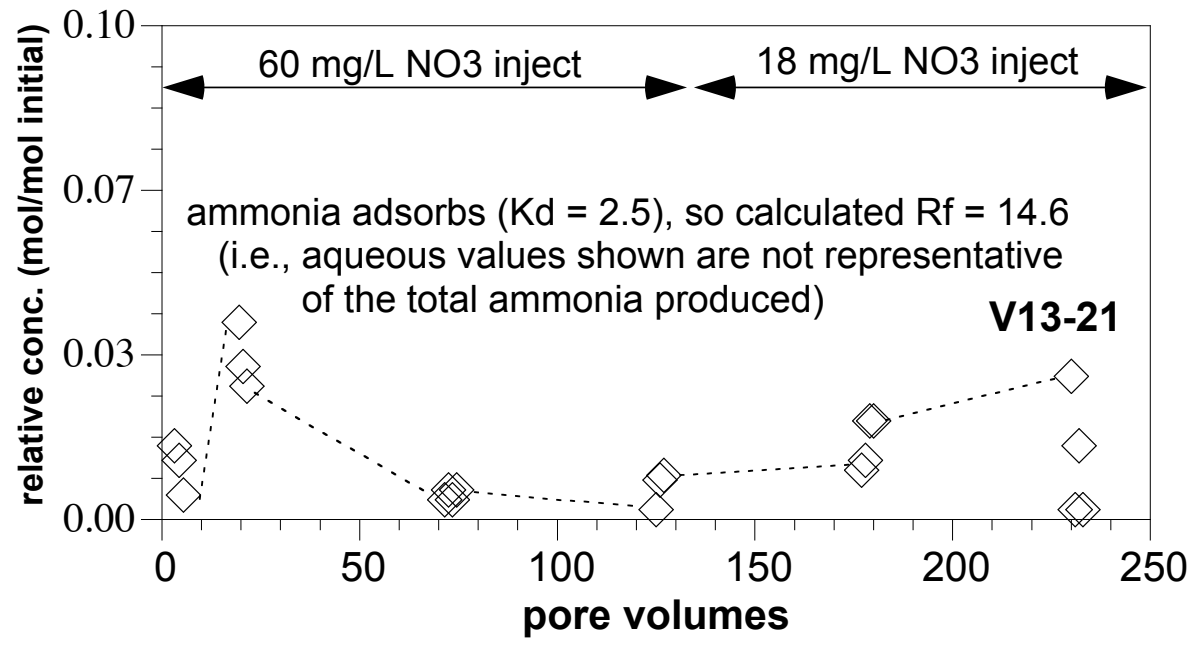

